\title{
Ghana: Enhanced Initiative for Heavily Indebted Poor Countries- Completion Point Document
}

This paper was prepared by staff of the International Monetary Fund and the World Bank in connection with the Executive Board's consideration of Ghana's progress under the Enhanced Initiative for Heavily Indebted Poor Countries. It is based on the information available at the time it was completed on June 15, 2004. The views expressed in this document are those of the staff team and do not necessarily reflect the views of the government of Ghana or the Executive Board of the IMF.

The policy of publication of staff reports and other documents by the IMF allows for the deletion of market-sensitive information.

To assist the IMF in evaluating the publication policy, reader comments are invited and may be sent by e-mail to publicationpolicy@imf.org.

Copies of this report are available to the public from

International Monetary Fund • Publication Services

$70019^{\text {th }}$ Street, N.W. • Washington, D.C. 20431

Telephone: (202) 623-7430 • Telefax: (202) 623-7201

E-mail: publications@imf.org •Internet: http://www.imf.org

Price: $\$ 15.00$ a copy

\section{International Monetary Fund \\ Washington, D.C.}





\section{INTERNATIONAL MONETARY FUND AND \\ INTERNATIONAL DEVELOPMENT ASSOCIATION}

\section{GHANA \\ Enhanced Heavily Indebted Poor Countries (HIPC) Initiative Completion Point Document}

Prepared by the Staffs of the International Monetary Fund and the International Development Association

Approved by Benedicte Vibe Christensen and Juha Kähkönen (IMF) and Callisto Madavo and Gobind Nankani (IDA)

June 15, 2004

Contents

Page

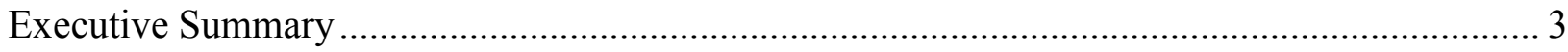

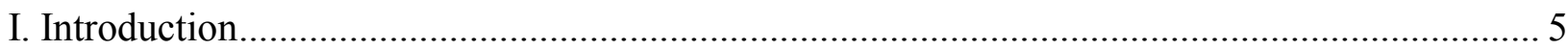

II. Assessment of Conditions for Reaching the Completion Point ……………………………....... 6

A. Ghana's Poverty Reduction Strategy ………………............................................... 8

B. Macroeconomic Performance, 2002-03 ……………................................................ 9

C. Key Structural Policies, Social Sector Reforms, and Floating Completion Point

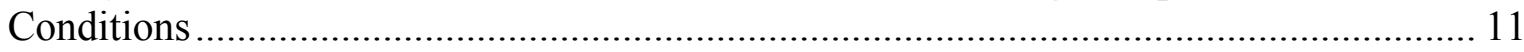

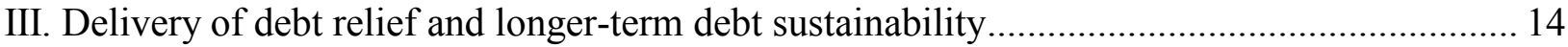

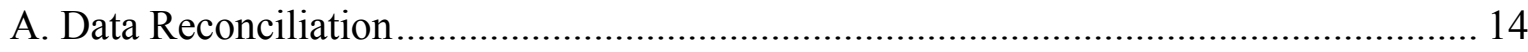

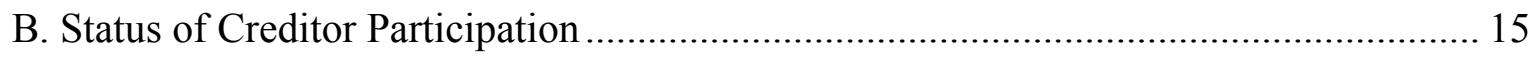

Multilateral Creditors.................................................................................... 15

Bilateral and Commercial Creditors …………................................................. 16

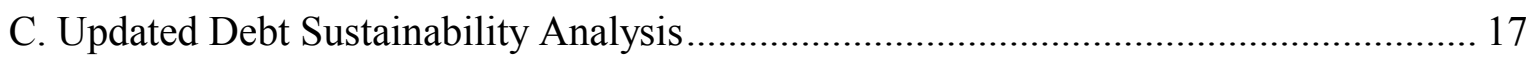

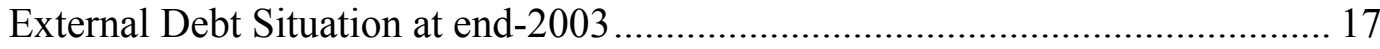

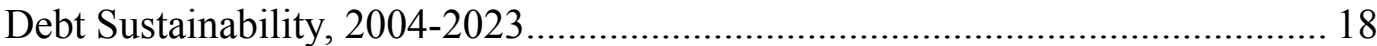

D. Sensitivity Analysis and Long Term Debt Sustainability .............................................. 19

Scenario 1: Terms of trade shock...................................................................... 19

Scenario 2: A reduction of external grants........................................................... 19

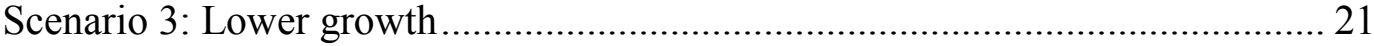

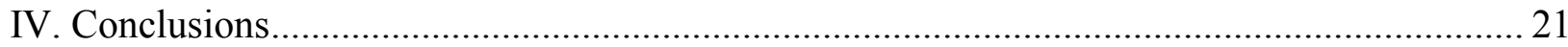

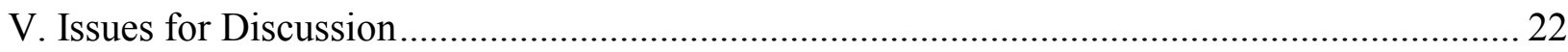


Boxes

1. Status of Triggers for the HIPC Floating Completion Point............................................... 6

2. Poverty-Related Expenditures, 2001-2004 ............................................................... 10

3. Macroeconomic Assumptions Underlying the Debt Sustainability Analysis at the Completion Point 18

Figure

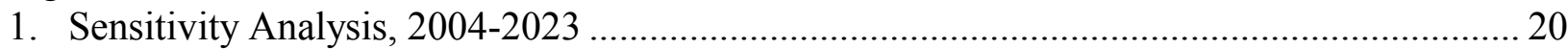

Tables

1. Selected Economic and Financial Indicators, 2001-23 .............................................. 25

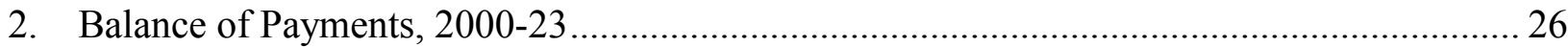

3. Central Government Budgetary Operations and Financing, 2000-23 .............................. 27

4. HIPC Initiative_-Assistance Under a Proportional Burden-Sharing Approach .................. 28

5. Comparison of Discount Rate and Exchange Rate Assumptions at end-2000

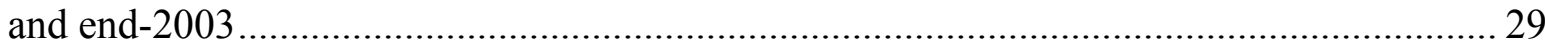

6. Comparison of Net Present Value of External Public Debt Between Decision Point and Completion Point ................................................................................................ 30

7. Nominal and Net Present Value of External Debt at Completion Point, end-2003 .............. 31

8. External Debt Service After Full Implementation of Debt-Relief Mechanism .................... 32

9. Net Present Value of External Debt, 2003-2023 ............................................................. 33

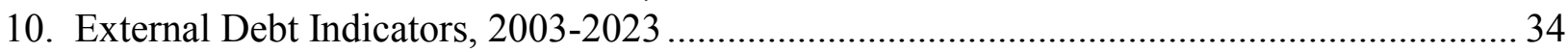

11. Sensitivity Analysis, 2004-2023 …........................................................................... 35

12. Delivery of IDA Assistance Under the Enhanced HIPC Initiative, 2001-2023 .................. 36

13. Delivery of IMF Assistance Under the Enhanced HIPC Initiative ................................. 37

14. Status of Creditor Participation Under the Enhanced HIPC Initiative................................ 38

15. Paris Club Creditors' Delivery of Debt Relief Under Bilateral Initiatives Beyond the

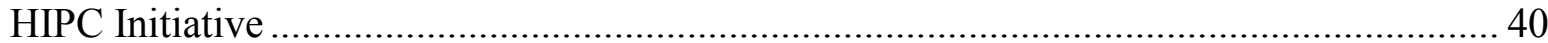

16. HIPC Initiative: Status of Country Cases Considered Under the Initiative, end-May 2004

Appendix

1. Debt Management Assessment ................................................................................ 23 


\section{EXECUTIVE SUMMARY}

In February 2002, the Executive Boards of the IMF and the IDA agreed to support a comprehensive debt reduction package for Ghana under the enhanced Heavily Indebted Poor Countries (HIPC) Initiative. At that time, a set of floating triggers was agreed for Ghana to reach the completion point under the Initiative. This paper assesses Ghana's progress in meeting those triggers, and seeks the Boards' approval of the completion point, including a waiver of one of the completion point triggers.

At the decision point, debt relief required under the enhanced HIPC Initiative to lower the net present value (NPV) of debt-to-government revenue ratio to 250 percent was estimated to be US $\$ 2,186$ million. This relief represented a 56.2 percent reduction in debt, in NPV terms, after the full use of traditional debt relief mechanisms.

In the view of the staffs of the IMF and the IDA, Ghana has made satisfactory progress on the implementation of the conditions for reaching the floating completion point:

- $\quad$ A Poverty Reduction Strategy Paper was prepared, and has been implemented over the past year;

- $\quad$ Macroeconomic stability has been maintained; and

- $\quad$ All but one of the key structural reforms and social measures monitored under the framework have been met. The trigger that was not met relates to the implementation of an automatic adjustment formula for petroleum pricing.

In light of additional information received from creditors and a new reconciliation of external debt to end-2003, the staffs have revised the DSA that was presented at the time of the decision point for Ghana. This new reconciliation exercise revealed the need for a minor change to update the database used for the decision point, but this does not imply a need to revise the common reduction factor of 56.2 percent. As of May 2004, satisfactory financing assurances with respect to creditor participation in enhanced HIPC assistance for Ghana have been obtained.

The revised DSA shows that Ghana's external debt is likely to:

- remain sustainable over the projection period (2004-2023), with the NPV of the external debt-to-exports ratio showing a steep decline from levels above 200 percent at end-2003 to fairly stable levels below 125 percent, and the NPV of external debt-to government revenue declining from 350 percent to 118 percent over the same period; and

- $\quad$ remain robust to moderate country-specific shocks, even of a persistent nature. However, the sensitivity analysis also suggests that if Ghana were affected by permanent adverse shocks, or a combination of shocks, debt sustainability could once again be compromised. 
Overall policy implementation by the Ghanaian authorities since the decision point has generally been satisfactory, although the nonobservance of the trigger on the automatic adjustment of petroleum prices signals a weakness in structural policies. However, the staffs believe that the fundamental reform of petroleum pricing to which the authorities have committed will address the problems in this area, most importantly, by eliminating the government's involvement in the price-setting process. 


\section{INTRODUCTION}

1. In February 2002, the Executive Boards of the International Monetary Fund (IMF) and the International Development Associations (IDA) agreed to support a comprehensive debt reduction package for Ghana under the enhanced Heavily Indebted Poor Countries (HIPC) Initiative at the decision point. ${ }^{1}$ At that time, a set of floating triggers was established for Ghana to reach the completion point. This paper assesses Ghana's progress in meeting those triggers, and seeks the Boards' approval of the completion point, including a waiver of one of the completion point triggers.

2. At the decision point, debt relief required under the enhanced HIPC Initiative to lower the net present value (NPV) of debt-to-government revenue ratio to 250 percent was estimated to be US\$2,186 million. ${ }^{2}$ This relief represented a 56.2 percent reduction in debt, in NPV terms, after the full use of traditional debt relief mechanisms. The Boards also agreed to provide Ghana with interim assistance to cover part of the debt service falling due to the IMF and IDA until Ghana reached the floating completion point. The IMF provided interim debt service relief in an amount equivalent to SDR 25.1 million in nominal terms between February 2002 and May 2004, while IDA provided interim relief amounting to US $\$ 98$ million over the same period. In addition, both the AfDB and the EU/EIB provided interim relief in the amount of US\$52 million and EUR4.7 million, respectively.

3. The rest of the paper is organized as follows. Section II discusses Ghana's performance in observing the requirements for reaching the floating completion point under the framework, including implementation of the national poverty reduction strategy. Section III describes the delivery of debt relief and longer-term debt sustainability, while the conclusions are summarized in section IV. Section V presents some issues for discussion by Executive Directors in considering the staffs' proposal to bring Ghana to the completion point.

\footnotetext{
${ }^{1}$ See http://www.imf.org and http://www.worldbank.org/hipc, Ghana-Enhanced Heavily Indebted Poor Countries (HIPC) Initiative Decision Point Document, February 2002.

${ }^{2}$ In April 1997, the fiscal revenue/openness criteria were established to allow for the possibility that, for countries such as Ghana with a high export base, reaching the debt-to-export criteria targets may still leave the country with an unsustainable external debt burden relative to government revenue. In order to qualify for this window, a country must have an export-to-GDP ratio of at least 30 percent, and a fiscal revenue-to-GDP ratio of at least 15 percent, using an average of the last three years of actual data. With an export-to-GDP ratio of 37 percent and a fiscal revenue-to-GDP ratio of 17 percent, Ghana qualified for debt relief under the fiscal revenue/openness criteria, which provides significantly more relief than using the debt-to-exports ratio.
} 


\section{Assessment of Conditions for Reaching the Completion Point}

\section{Ghana has made satisfactory progress on the implementation of the conditions} for reaching the floating completion point (Box 1). To reach this point under the framework, Ghana committed to: prepare a Poverty Reduction Strategy Paper and satisfactorily implement the strategy for at least one year; maintain macroeconomic stability; and undertake key structural reforms and social measures monitored under the Initiative, as agreed at the decision point. As detailed below, all but one of the specified triggers have been met. The trigger that was not met relates to implementation of an automatic adjustment formula for petroleum pricing. This is an important structural measure, and the case for proceeding to the completion point despite its non-implementation is set out in section II.C.

Box 1. Ghana: Status of Triggers for the HIPC Floating Completion Point

Triggers
PRSP. Preparation of a full PRSP and satisfactory
implementation for at least one year, as evidenced by the joint
staff assessment of the country's annual progress report.
Status

Met. The full PRSP was finalized and sent to the IMF and IDA in February 2003 and discussed by the IMF and IDA Boards in May 2003. The 2003 PRSP Annual Progress Report was completed in May 2004 and the Joint Staff Assessment submitted to the Boards in June 2004.

Macroeconomic stability. Continued maintenance of Met. A new-three year PRGF arrangement was approved in May 2003 and the first macroeconomic stability as evidenced by satisfactory implementation of the PRGF-supported program. review completed in December 2003. The second review is planned to be completed in June 2004.

Use of budgetary savings. The use of budgetary savings from interim debt service relief have been used in the priority areas and monitored in the framework for poverty reduction expenditures. Information on the use of these savings and on poverty expenditures has been published in time to be considered in a public review of GPRS implementation, as input to the annual progress report on the GPRS. The increase in total spending on these priorities must equal or exceed HIPC relief (less relief used for domestic debt reduction) during the interim period.

\section{Governance}

- Procurement reform. Regulatory and oversight body to implement new procurement code has been established.
Met. The tracking system is in place and HIPC relief is additional to budgetary spending, mostly on basic infrastructure and social sectors. The 2003 PRSP Annual Progress Report provides information on use of the resources and on poverty-related expenditures.

Met. In December 2003, Procurement Act was passed by parliament. Members of the Public Procurement Board were appointed by the President and their inauguration is planned for June 2004. The position of Chief Executive of the Secretariat of the Board has already been advertised and selection to fill the position is expected by the end of July 


\begin{tabular}{|c|c|}
\hline & $\begin{array}{l}\text { 2004. MOEFP has already instructed public } \\
\text { procurement bodies to form Entity Tender } \\
\text { Committees. }\end{array}$ \\
\hline $\begin{array}{l}\text { Internal audit. Operational internal audit capacity has } \\
\text { been established through full staffing of existing internal } \\
\text { audit positions. }\end{array}$ & $\begin{array}{l}\text { Met. Existing positions are fully staffed, but } \\
\text { quality of internal audit remains weak. } \\
\text { Internal Audit Act, approved in December } \\
\text { 2003, aims to improve quality and } \\
\text { management of audit function. Members of } \\
\text { the Internal Audit Agency Board were } \\
\text { appointed by the President and their } \\
\text { inauguration is planned for June 2004. The } \\
\text { position of Director General of the IAA has } \\
\text { already been advertised and selection to fill } \\
\text { the position is expected by the end of July } \\
2004 \text {. }\end{array}$ \\
\hline $\begin{array}{l}\text { Public expenditure management } \\
\text { - Reports on cash expenditures and commitments by } \\
\text { MDAs, classified by function, have been published } \\
\text { monthly in the government gazette, following } \\
\text { implementation of new reporting system. } \\
\text { - A computer-based financial management information } \\
\text { system to underpin the new expenditure reporting system } \\
\text { has been installed on a pilot basis in the Ministry of } \\
\text { Finance, CAGD, and at least two key sector ministries. }\end{array}$ & $\begin{array}{l}\text { Met. New cash management and } \\
\text { commitment control system implemented in } \\
\text { all ministries by end-December } 2003 \text {. New } \\
\text { reporting system implemented and reports } \\
\text { are published in the monthly gazette. } \\
\text { Met. System has been installed on a pilot } \\
\text { basis at the MOF, CAGD and the Accra- } \\
\text { based operations of the ministries of health, } \\
\text { education, and roads and transport (albeit } \\
\text { with partial functionality). The system will } \\
\text { be rolled out to another four MDAs by early } \\
2005 \text {. }\end{array}$ \\
\hline $\begin{array}{l}\text { Decentralization of government functions } \\
\text { - Devolution of responsibilities to local districts, as } \\
\text { evidenced by (i) submission to Parliament of a local } \\
\text { service bill to enable the decentralization of human } \\
\text { resource management to local authorities; and } \\
\text { (ii) development of District Composite Budgets in pilot } \\
\text { districts. }\end{array}$ & $\begin{array}{l}\text { Met. Local Government Services Act was } \\
\text { passed by parliament in December } 2003 . \\
\text { District composite budgets prepared in three } \\
\text { pilot districts (Dangme East, Dangme West, } \\
\text { and Akwapim North). }\end{array}$ \\
\hline $\begin{array}{l}\text { Education } \\
\text { - The primary gross enrollment rates for girls has } \\
\text { increased from } 72 \text { percent in } 2000 \text { to } 74 \text { percent. }\end{array}$ & $\begin{array}{l}\text { Met. In the } 2002 / 2003 \text { academic year, the } \\
\text { primary gross enrollment rate for girls } \\
\text { reached almost } 78 \text { percent. }\end{array}$ \\
\hline $\begin{array}{l}\text { Health } \\
\text { - The percentage of households with access to safe water } \\
\text { has increased from } 40 \text { percent in } 2000 \text { to } 46 \text { percent in } \\
\text { rural areas. } \\
\text { Recurrent health expenditures at district and lower level } \\
\text { governments have risen from } 42 \text { percent of the total } \\
\text { recurrent health budget in } 2000 \text { to } 45 \text { percent. }\end{array}$ & $\begin{array}{l}\text { Met. Rural water coverage is estimated at } \\
46.4 \text { percent in } 2003 \text {. } \\
\text { Met. Estimated share of recurrent health } \\
\text { expenditures at district and lower levels } \\
\text { reached } 49.6 \text { percent in } 2003 \text {. }\end{array}$ \\
\hline
\end{tabular}




\section{Energy Sector}

- An automatic price adjustment mechanism has been put in place and implemented monthly to reflect changes in international market prices in local currency in the petroleum sector, and includes all taxes incorporated into the adjustment formula at end-March 2002.

- A strategy for achieving full economic pricing in the electricity sector, including lifeline pricing to ensure affordability for low income users, has been implemented.
Not met. Pricing formula was put in place in 2003 but has not been implemented. A new regulatory regime that will give freedom to oil marketing companies to set prices (according to a prescribed formula), and that credibly removes government influence over pricing decisions, will be announced by Cabinet in June 2004. The new regime is expected to become effective on February 15, 2005.

Met. Strategy established and implemented since August 2002.

\section{A. Ghana's Poverty Reduction Strategy}

5. Following extensive consultations with civil society and other stakeholders, the authorities finalized the Ghana Poverty Reduction Strategy (GPRS) in February 2003. Based on its analysis of the determinants and linkages to poverty, the GPRS set out five pillars - macroeconomic stability, production and employment, human resource development, special programs for the vulnerable and excluded, and governance — on which the government would base its strategy for poverty alleviation. The joint staff assessment (JSA) of the GPRS concluded that the policies contained in the GPRS provided a sound framework for implementing the government's anti-poverty agenda. ${ }^{3}$

6. Implementation of the GPRS was broadly satisfactory during 2003, as described in the Annual Progress Report (APR). ${ }^{4}$ The APR was prepared by the government with technical assistance from bilateral donors, and actively involved national inter-agency poverty monitoring groups. Using a wide set of financial, economic and social indicators, the APR suggested that good progress was made on several fronts, while noting weaker performance in some others. The report highlighted, in particular, improved macroeconomic performance, and increased alignment of the GPRS with the budget formulation. The report acknowledged, however, the continuation of costly quasi-fiscal activities (in petroleum and utility pricing), the poor delivery of some social services, and the deterioration of some health

\footnotetext{
${ }^{3}$ See www.imf.org and www.worldbank.org, Ghana-Joint Staff Assessment of the Poverty Reduction Strategy Paper, March 2003.

${ }^{4}$ See Ghana-Joint Staff Assessment of the Annual Progress Report of the Poverty Reduction Strategy Paper, June 2004, www.imf.org and IDA Report No. 29181-GH.
} 
indicators (infant, and under 5-mortality rates). In these areas, the APR recommended midcourse policy corrections, in the context of the overall strategy. ${ }^{5}$

7. Poverty-related expenditure in Ghana has been significantly increased since the GPRS was established (Box 2). Such spending in 2003 was 2 percent of GDP higher than in 2001, exceeding the annual amount of HIPC relief provided. ${ }^{6}$ Spending for basic education and health care expanded the most rapidly, confirming the strategy's emphasis on social service delivery in deprived regions and for vulnerable groups.

\section{Looking ahead, the authorities have stated their intention to extend the GPRS} analytical framework, and if necessary augment future poverty spending, with a view to achieving the Millennium Development Goals (MDGs). Ghana appears poised to meet many of its MDGs, although an updated analysis of the incidence of poverty, and an investigation into factors underlying an apparent deterioration in key health care indicators, need to be undertaken. ${ }^{7}$ Ongoing work to cost the MDGs, along with a review of the medium-term health expenditure strategy, will form inputs for a possible expansion of health care spending from 2005 onward; an increase of around 1 percent of GDP could be accommodated within the existing macroeconomic framework, even without additional donor assistance.

\section{B. Macroeconomic Performance, 2002-03}

\section{Macroeconomic performance has strengthened since the decision point}

(Table 1). The rate of economic growth in 2003 was 5.2 percent (one percentage point higher than in 2001) and real per capita incomes increased at the fastest pace in a decade. Nearrecord cocoa production has been the driving factor behind recent activity, highlighting the economy's ongoing reliance on this commodity for economic prosperity. Inflation developments have been uneven over the past year, largely on account of a one-time adjustment of petroleum prices, but they have been more favorable recently. By April 2004, 12-month CPI inflation slowed to 11.2 percent from over 23 percent at end-2001. The external sector has performed well over the two-year period, with a surplus emerging in the current account (including official grants) in 2002, and reaching 13/4 percent of GDP in 2003. Strong foreign inflows from cocoa and gold exports, and personal remittances, have brought

\footnotetext{
${ }^{5}$ For details, see Table 1.4 in the Annual Progress Report of the GPRS.

${ }^{6} \mathrm{HIPC}$ relief is measured as total relief provided less that portion that Ghana would have received under traditional mechanisms. As indicated in the decision point document, 20 percent of HIPC relief, so defined, would be used to reduce domestic debt and 80 percent to raise poverty-related spending.

${ }^{7}$ Ghana's progress towards meeting the MDGs is detailed in Chapter 9 of the Annual Progress Report of the GPRS.
} 
gross international reserves to about 4 months of imports at the end of last year, compared with only 1.2 months at the end of 2001 .

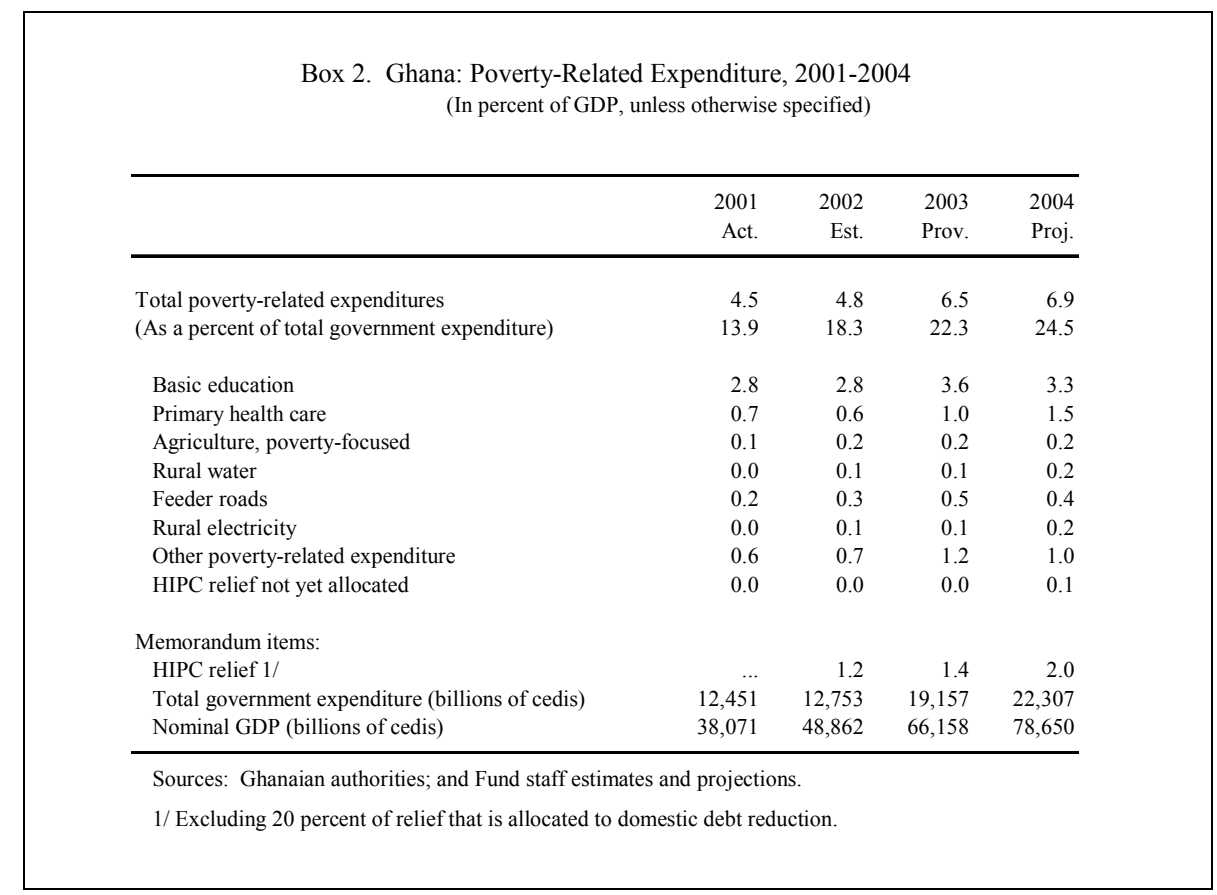

10. Macroeconomic stabilization reflects, in large part, the strong fiscal

consolidation in 2003. During 2002, weaknesses in control over the wage bill and petroleum subsidies led to fiscal overruns. Fiscal discipline improved markedly in 2003, however, and net domestic borrowing by the government was eliminated. This implied a sharp reduction of domestic debt relative to GDP (from almost 27 percent at end-2001, to below 20 percent), in line with a central anchor of the poverty reduction strategy. Efforts to consolidate the fiscal position have been supported by rising tax revenue, with improved administration and several new measures. Significantly higher than expected tax revenue has a favorable impact on Ghana's debt sustainability (see below). Monetary policy continues to aim at price stability, and assuming continued fiscal discipline, is on track to reach the authorities' inflation target of around 7 percent by the end of this year.

11. On balance, Ghana's performance under the PRGF-supported arrangement has been satisfactory, and the Fund staff is recommending completion of the second review under the arrangement. All but one of the program's quantitative performance criteria at end-December 2003 were observed. Two structural performance criteria were not implemented, relating to the automatic adjustment of petroleum and utility prices. The problems with electricity and water tariffs have been technical in nature, and the government remains committed to the full implementation of the formulas for adjustment of electricity and water tariffs. The difficulties with petroleum pricing, by contrast, have been more severe, culminating in a government decision in early 2004 to refrain from any price increase ahead of the general election in December, over concern for political unrest and social instability. 
The institutional weaknesses that have contributed to poor policy implementation in this area, and the authorities' proposals for addressing those weaknesses, are discussed in the next section. As far as the 2004 budget is concerned, the nonadjustment of petroleum prices generates a substantial bill for unplanned subsidies (equivalent to a projected 1.4 percent of GDP). The fiscal costs of these subsidies are being met through higher revenue, a lower debt repayment this year, and spending cuts. These adjustments can be accommodated in the program without compromising the medium-term domestic debt reduction and povertyrelated expenditure targets. However, the fiscal position is vulnerable to rising oil prices, and a loss of discipline ahead of the December election.

\section{Key Structural Policies, Social Sector Reforms, and Floating Completion Point Conditions}

\section{Over the past two years, the authorities have made generally satisfactory} progress in structural and social sector reform, as detailed in the Annual Progress Report of the GPRS, as well as in the President's Report for the Ghana Poverty Reduction Support Credit. ${ }^{8}$ In addition to developing and implementing a full PRSP for at least a year, and maintaining macroeconomic stability under a Fund-supported program, the authorities observed all but one of the completion point triggers (Box 1 above):

- Governance: The establishment of a procurement regulatory and oversight body, and the development of an internal audit capacity laid the foundation for improving governance and transparency in the use of public resources. In the area of procurement, a strengthening of the legal framework (Public Procurement Law), and stepped up enforcement of rules and regulations (by the Public Procurement Board that is to be inaugurated in June 2004) will promote value for money, and accountability of public institutions. The preparation of new standard tender documents and a training manual has begun, and entities engaged in public procurement have been instructed to form Entity Tender Committees and start processing all procurement in accordance with the new law. The potential for enhancing the quality and capacity of internal auditing was advanced through the passage of the Internal Audit Agency Act. This legislation creates an institution with the mandate to coordinate and raise the standard of internal audit activities in government ministries, departments and agencies (MDAs). The position of Director General of the new Internal Audit Agency Board has already been advertised and is expected to be filled by the end of July 2004.

- $\quad$ Public expenditure management: The tracking of poverty-related expenditures (including those funded from HIPC relief) and the monitoring of GPRS

\footnotetext{
${ }^{8}$ See the President's Report for the Ghana Second Poverty Reduction Support Credit (PRSC 2), IDA29177-GH.
} 
implementation have been facilitated by enhancements to public expenditure management. The key innovations relate to cash and commitment control of budgetary expenditures in all MDAs; the reconciliation of fiscal and banking records on a routine basis; and a computer-based financial management information and reporting system (Budget and Public Expenditure Management System, BPEMS). The implementation of BPEMS has been slower than expected, but progress is now well in hand. The Ministry of Finance and the Controller Accountant General's Department migrated to BPEMS in mid-2003. The configuration and setup of BPEMS in the Accra-based operations of the ministries of health, education, and roads and transport has been completed, and three of the five modules are now fully functional. The installation of BPEMS in another four MDAs will be finalized early next year.

- Decentralization: The passage of a Local Government Service Law in December 2003 devolved human resource management responsibilities to local districts, increasing the authority and accountability of local governments, and providing for civil society participation. The process will continue under a National Decentralization Action Plan, recently endorsed by cabinet, that seeks ultimately to transfer key responsibilities from central MDAs to the Regional Coordinating Councils and District Assemblies. The composite budgets, developed recently on a pilot basis in three district assemblies (Akwapim North, Dangme East and Dangme West), will gradually be extended nationwide, with a view to increasing the transparency of aggregate expenditures at the district level.

- $\quad$ Education: Performance in raising the gross enrollment rate for girls in primary education exceeded what was called for under the completion point trigger. Effective targeting of policy interventions also reduced regional disparities in girls' education, with particularly marked improvements in the three most under-served regions (Northern, Upper East and Upper West). In general, the favorable outcomes reflect the removal of financial barriers in access to education, and improvement in the intrasectoral resource allocation. Implementation of the recently approved Education Strategic Plan will contribute to Ghana's achievement of the MDGs and "Education for All" goals.

- Health: Attainment of the completion point triggers for health signals progress in policy implementation, although some health sector outcomes have failed to meet expectations, notably infant- and under-5 mortality rates. Recent policy initiatives have sought to refocus health resources on under-served regions, including through community-based health planning and services, launching of regional delivery programs to reduce under-five and maternal mortality rates, and implementation of a needs-based formula to guide the intra-sectoral allocation of resources.

13. Progress in tackling the structural problems relating to the energy sector has not been as strong as in other areas. In the power sector, the strategy for achieving full cost 
recovery with lifeline provisions, to facilitate access to electricity by low-income customers, was launched in 2002. To ensure that electricity tariffs are aligned with current market conditions, an automatic adjustment mechanism is in place. The Public Utilities Regulatory Commission (PURC) has been charged with the responsibility of administering the mechanism, and it has done so, albeit with occasional delays. Progress has also been made in laying the foundations for a more stable and efficient supply of electricity, through the implementation of a power reform project approved by cabinet in August 2003.

\section{The completion point trigger requiring the implementation of the automatic} adjustment formula for petroleum prices was not met. At the time of the decision point, the authorities had adopted a pricing formula as a means to ensure automatic adjustment of prices, with the intention of depoliticizing such decisions. However, when the formula called for price increases in late 2002, the government postponed the adjustments until it became clear that the subsidy cost had become unsustainable. In January 2003, petroleum prices were raised by an average of 90 percent and, recognizing that the mechanism was not functioning as intended, the government turned over responsibility for calculating and implementing monthly price changes to a newly independent National Petroleum Tender Board (NPTB). This limited reform also failed, however, as the government intervened in late 2003 to block required prices increases, and then decided (in early 2004) that owing to concerns about possible social instability, no adjustment could be made ahead of the December 2004 elections.

\section{These experiences led the authorities to conclude that a more fundamental} reform was required, to convince the public that government was no longer responsible for adjustments in petroleum prices. They announced the broad elements of a petroleum sector deregulation strategy in the 2004 budget statement, and have since elaborated on the new pricing regime they intend to implement. They considered full price liberalization, with anti-trust mechanisms to address concerns over collusive behavior on the part of the private oil marketing companies (OMCs). This option, however, was rejected because of the lack of capacity to create anti-trust legislation and institutions. They therefore decided to give OMCs full authority to make price adjustments without prior approval of any governmental or quasigovernmental agency, but (to address the risk of collusion) required that adjustments be made according to a prescribed formula. Under this regime, the decisions of the OMCs would be subject only to ex post review, by an oversight body on which the government would be represented, so as to reassure the public that the pricing formula is being properly implemented. ${ }^{9}$

\footnotetext{
${ }^{9}$ It is envisaged that the oversight body and the OMCs would also periodically review the parameters of the formula, which could be modified by mutual consent.
} 
16. In June 2004, Cabinet is expected to endorse and announce publicly the key features of the new pricing regime, and the details are to be incorporated in a comprehensive petroleum sector deregulation bill to be presented later this year. The new regime is expected to be implemented by mid-February 2005 at the latest, following the election and inauguration of the new administration, at which time the political context for the reform should be more favorable. It is critically important that the new regime be implemented as announced, and on schedule. In this regard, completion of the third review under the Fund-supported program will not take place until after the new regime is fully implemented. The interests of the low-income consumers of these products will be taken into account in setting the structure of petroleum taxes, which will replace the inefficient and ineffective system of implicit cross-subsidization that now exists. The setting of the taxes will be informed by the findings of a poverty and social impact analysis of petroleum pricing which is expected to be completed shortly.

17. The staffs believe that the new and potentially more robust pricing regime will address effectively the weaknesses of previous failed mechanisms, and will provide strong assurances that future budgets will be insulated from world oil price fluctuations. On this basis, in view of the strong performance in other policy areas, and given the conditionality for completion of the third review under the Fund-supported program, the staff recommends a waiver of the related completion point trigger.

\section{DELIVERY OF DEBT RELIEF AND LONGER-TERM DEBT SUSTAINABILITY}

\section{A. Data Reconciliation}

18. In light of additional information received from creditors and a new reconciliation of external debt to end-2003, the staffs have updated the DSA that was presented in the decision point document for Ghana. ${ }^{10}$ This new reconciliation exercise revealed the need for minor changes to the database used for the decision point but this does not imply a need to revise the common reduction factor of 56.2 percent. ${ }^{11}$ The total relief envisioned under the enhanced HIPC Initiative will, therefore, remain at the decision point level, US\$2,186 million in NPV terms.

19. At end-2003, Ghana's debt stock in NPV terms was US\$5.5 billion, before the use of traditional debt-relief mechanisms (Table 7). Multilateral creditors accounted for 60 percent of the overall NPV, with claims of the IDA and the IMF amounting to 43 and 7 percent, respectively. Paris Club creditors represented 34 percent of the total outstanding debt, and non-Paris Club and commercial creditors 5 percent. Compared with the DSA

${ }^{10}$ Approximately 91 percent of the total debt stock can be considered reconciled, compared with 86 percent at the time of the decision point DSA.

${ }^{11}$ At end-2003, US\$ 14 million in loans had not been previously reported by two bilateral creditors. 
performed at the decision point, this structure shows an increase in the share of multilateral debt of about 10 percentage points, reflecting the predominance of multilateral creditors in new borrowing since then.

\section{B. Status of Creditor Participation}

\section{Multilateral Creditors}

20. Required debt relief from multilateral creditors under the enhanced HIPC Initiative, as estimated in the decision point document, amounts to US\$1,102 million in 2000 NPV terms (Table 4). The IMF, IDA, AfDB, and the EU/EIB have provided interim assistance. Other creditors, namely the OPEC Fund, BADEA, NDF and IFAD, have committed themselves to providing their share of relief once Ghana reaches its completion point. Debt relief from multilateral creditors represents 50 percent of the total, and at the completion point, breaks down as follows:

- IDA, the largest multilateral creditor, is expected to provide relief amounting to US\$782 million in NPV terms, via a 67 percent debt service reduction during 20022022. IDA provided US\$98 million in interim nominal relief;

- $\quad$ Debt relief from the IMF amounts to US\$112 million in NPV terms, and is expected to be delivered via grants targeted for debt service reduction. The Fund provided SDR25.1 million in interim nominal relief;

- Debt relief from AfDB is expected to amount to US\$131 million in NPV terms. During the interim period AfDB provided US\$52 million in nominal relief, mainly delivered through debt service reduction financed through the HIPC Trust Fund;

- $\quad$ The EU/EIB is expected to provide US\$41 million of relief in NPV terms, and provided EUR4.7 million in interim nominal relief;

- $\quad$ As for the other multilateral creditors, the OPEC Fund is expected to disburse a US\$6 million loan (on concessional terms) at the completion point, to partially refinance existing loans; IFAD and NDF are expected to provide 100 percent debt service cancellation for a period until their NPV target relief of US\$18 million and US\$5.4 million, respectively, is achieved; and the precise modalities for delivery of BADEA's relief of US\$7.1 million (in NPV terms) are yet to be established. 


\section{Bilateral and Commercial Creditors}

21. Paris Club creditors have agreed in principle to provide assistance under the enhanced HIPC Initiative of US\$829 million in NPV terms. ${ }^{12}$ Bilateral agreements have been already signed with ten Paris Club creditors. Under the terms of those agreements, Germany, Italy, the Netherlands, the United Kingdom, and the United States have already committed to provide 100 percent flow relief during the interim period. Japan and Spain provided 100 percent rescheduling and Canada 95 percent cancellation. Agreements are pending with France, Japan, Norway, and Sweden, but negotiations are well advanced, and these countries have been providing interim relief along with the rest of the Paris Club. Most Paris Club creditors have indicated their willingness, at the completion point, to provide debt relief beyond that required under the HIPC Initiative. This would provide additional relief of about US\$0.6 billion in end-2003 NPV terms (Tables 6 and 15).

\section{Non-Paris Club bilateral and commercial creditors are expected to provide} treatment comparable to that of Paris Club creditors, with assistance under the enhanced HIPC Initiative amounting to US\$256 million in NPV terms. All official bilateral creditors have indicated their commitment to provide relief under the enhanced HIPC initiative. China has signed an agreement with Ghana that effectively cancelled several loans and the Saudi Development Fund has signed a Memorandum of Understanding indicating their intention to provide relief after the completion point. (During the interim period they provided flow rescheduling on Naples terms.) The Kuwait Development Fund has provided stock relief on Naples terms only. Korea and India are still in negotiations with Ghana, although the latter's outstanding claims are minimal.

23. Concerning commercial creditors, the Ghanaian authorities continue their best efforts to obtain full HIPC relief in accordance with the principles of the enhanced Initiative. Some commercial creditors' loans have been taken over by the official agencies of their respective countries and their debts will be treated under the Paris Club. One Korean commercial creditor (Samsung Corporation) has not agreed to provide debt relief. The loans outstanding, which amounted to US\$130.3 million at end-2000, are fully collateralized by proceeds from foreign exchange receivables that are being deposited in an off-shore account. During the interim period debt service to this creditor was paid in a timely manner. The DSA assumes that relief will be provided on these loans. However, since Ghana's debt-to-

\footnotetext{
12 After the decision point, Paris Club creditors decided to change their cutoff date for Ghana from January 1983 to June 1999. This change significantly increased the pool of debt eligible for debt relief. The new cutoff date allowed Paris Club creditors to provide the necessary relief to the country during the interim period. In line with this change, the relevant HIPC calculations in the updated DSA are based on the 1999 cutoff date, and the traditional relief scenarios use the 1983cutoff date. As a consequence, the decision- and completion-point NPVs are not comparable. The change in the cutoff date does imply debt service that is more back loaded, but the total relief to be delivered at completion point in NPV terms remains the same.
} 
government revenue ratio after enhanced HIPC relief is well below the threshold, other creditor's contributions to the overall debt relief should not change if this relief is not provided.

24. As of May 2004, satisfactory financing assurances with respect to creditor participation in enhanced HIPC assistance for Ghana have reached 89.6 percent of the total assistance approved in February 2002, and are sufficient for granting irrevocable relief from the IMF and IDA at the completion point. Multilateral creditors have given assurances to participate, representing 50.4 percent of total debt relief in NPV terms, as calculated in the decision point document. Furthermore, Paris Club creditors representing 37.9 percent of the targeted assistance have provided assurances of their participation. A number of non-Paris Club creditors have also agreed to participate but have not signed any formal agreements so far. The Ghanaian authorities are actively seeking the official endorsement of the remaining creditors.

\section{Updated Debt Sustainability Analysis}

\section{External Debt Situation at End-2003}

25. The DSA performed at the decision point has been updated jointly by the Ghanaian authorities and the staffs of the IMF and IDA, on the basis of loan-by-loan data for nominal debt disbursed and outstanding at end-2003. The exchange rates and discount rates used for calculating Ghana's nominal and NPV debt as of end-2003 are presented in Table 5.

26. Based on the reconciled debt data, Ghana's nominal stock of external debt before relief reached US\$7.5 billion at end-2003, compared with US\$6 billion at end2000. The new external borrowing after the decision point (amounting to US $\$ 1 \frac{1}{2}$ billion) is concessional, with most being provided by multilateral creditors.

27. In NPV terms, after the assumed application of traditional debt relief, Ghana's external debt at end-2003 is estimated at US\$5.0 billion, equivalent to 321 percent of government revenue (Table 6). The increase over what was projected at the decision point is more than accounted for by a reduction in discount rates and depreciation of the US dollar. Holding these parameters constant, the NPV of debt would be lower than at the decision point, since there has been 3 percent less net borrowing than was projected.

28. After the completion point, Ghana's debt is expected to remain below the NPV of debt-to-government revenue threshold established under the HIPC framework. Assuming full delivery at end-2003 of current debt relief committed under the HIPC Initiative, the NPV of debt would be expected to fall to US\$2.9 billion, equivalent to 189 percent of government revenues and 109 percent of exports of goods and services (Table 10, panel III). After the completion point, Ghana expects to be granted additional relief as indicated by bilateral creditors; after such additional relief, the NPV of external debt 
would be reduced further to US $\$ 2.4$ billion, equivalent to 152 percent of revenues and 88 percent of exports of goods and services. Baseline projections show that the NPV of external debt (after bilateral relief beyond HIPC) will rise gradually to US\$9.1 billion at end2023 but remain well within sustainable levels (Tables 6, 9, and 10, panel V).

\section{Debt Sustainability, 2004-2023}

29. The long-term macroeconomic framework for the completion point DSA is broadly in line with the earlier projections at the decision point (Box 3). Real GDP growth is projected to stay at 5 percent per annum, while inflation is expected to fall to around 5 percent by 2006 and remain there for the projection period. ${ }^{13}$ Export volumes are expected to grow by almost 4 percent on average, with central government tax revenue remaining at its current level of about 21 percent of GDP.

Box. 3 Ghana: Macroeconomic Assumptions Underlying the Debt Sustainability Analysis at the Completion Point

The baseline assumptions for the period 2004-23 include the following:

Real GDP growth of 5 percent per annum;

Inflation averaging 5 percent per annum;

Export volume growth of 3.8 percent per annum, while import volumes expand by about 4.5 percent;

Central government tax revenue is stable at about 21 percent of GDP;

Non-interest expenditure is projected to average 12 percent of GDP;

Current account deficit (including grants) of about 1.4 percent of GDP;

Gross borrowing and official grants are projected to remain below 5 percent of GDP, on average, with about one-third of external financing in the form of grants, and the rest from concessional lending.

30. The debt sustainability analysis shows that Ghana's external debt will remain sustainable during the projection period. The trajectory of the NPV of the external debt-toexports ratio shows a steep decline from levels above 200 percent before the completion point, to fairly stable levels below 125 percent after the completion point. Over the same period, the NPV of external debt-to-government revenue is projected to decline steadily from 350 percent to 118 percent (Table 10). Although nominal debt will gradually build up at approximately US\$320 million per year on a net basis, it is expected that these new loans will be on concessional terms.

31. In line with the significant stock of debt decline, the debt service-to-export and debt service-to-revenue ratios will reach comfortable levels after completion point. Debt service after HIPC relief is expected to average 4.7 percent of exports and 6.2 percent of revenue over the period 2004-23, both with stable profiles. These compare favorably with the

${ }^{13}$ The growth projection, which is unchanged from the decision point document, may be on the conservative side in the near term, given recent economic performance. 
10-year average pre-HIPC debt service levels (on a commitment basis) of 21 and 30 percent, respectively.

\section{Sensitivity Analysis and Long Term Debt Sustainability}

32. This section assesses Ghana's debt sustainability sensitivity under less favorable circumstances. Three scenarios are considered: a deterioration in the terms of trade, related to a drop in cocoa prices; a significant decline in grant financing; and a lower growth outlook, in line with historical performance.

\section{Scenario 1: Terms of trade shock}

33. Ghana's long-term debt sustainability is sensitive to a sustained decline of the price of cocoa. Cocoa accounts for about one-third of Ghana's total exports. In this scenario, a persistent price drop is assumed to occur in late 2004, affecting the (pre-sale) of cocoa exports in 2005 . The assumed decline is equivalent to one standard deviation of historical price levels of the past 20 years, and is assumed to continue through the projection period.

34. As a result of the lower cocoa prices, total exports would fall by US\$280 million per annum ( 5 percent) and government revenue would decline by 0.3 percentage points of GDP per annum, on average. If the financing gap generated by this shock were filled with additional debt on concessional terms, the terms of trade deterioration would lead to an NPV of debt in 2023 that is about US\$3.2 billion higher than the baseline, and hence, higher debt service as percent of revenue (Figure 1). Although the trajectory of the debt stock indicators would remain below HIPC threshold levels, the trend in debt service during later years would have a rapidly increasing slope.

\section{Scenario 2: A reduction of external grants}

35. The second scenario shows Ghana's external vulnerability to a significant reduction in grants as a source of financing. This "shock" is assumed to reduce the grant component in gross financing from about one-third to 10 percent, over the projection period. The financing gap created by this assumption is filled instead by additional borrowing on concessional terms. The grant shock would increase the debt stock by approximately US\$6.7 billion in NPV terms in 2023, compared with the baseline, and the NPV of debt-tofiscal revenue ratio by 81 percentage points to 199 percent and maintain a positive slope throughout the period.

36. This sustained reduction of grants would raise debt service by more than 1 percent of government revenue to 7.6 percent over the projection period. Likewise, debt service as a share of exports would increase by 1.2 percent to 5.9 percent. Most importantly, in this event, debt service levels after 2015 would trend rapidly towards unsustainable levels. 
Figure 1. Ghana Sensitivity Analysis, 2004-2023 (in percent)
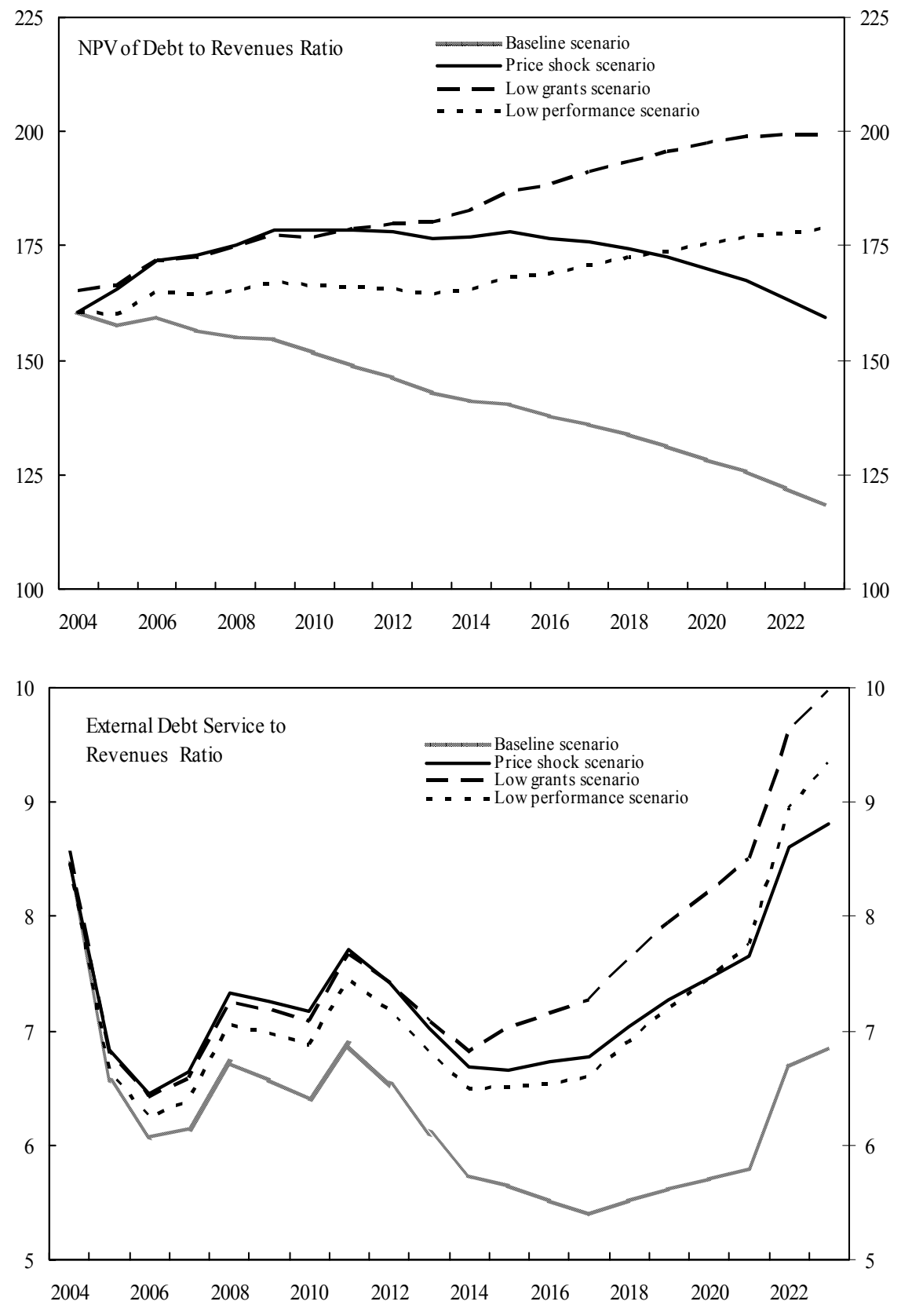

Sources: Ghanaian authorities; and staff estimates. 


\section{Scenario 3: Lower growth}

37. Compared with the baseline, a scenario of lower growth implies a much more limited reduction of its debt burden, with debt service ratios gradually increasing over the projection period. This scenario assumes a growth path (4 percent per annum) that is broadly consistent with economic performance over the past decade, compared with 5 percent in the baseline. Lower growth in turn affects government revenue, creating an average of 1 percent of GDP in additional financing needs per annum. Three-quarters of this gap is assumed to be filled by additional external borrowing, and the remainder by adjustment.

38. Lower economic growth would lead to an average increase in debt service of almost 1 percentage points of revenue, and 1.1 percentage points of exports. The NPV of debt would also increase by US\$3.3 billion at the end of the projection period, compared to the baseline, but throughout the period would still remain almost flat and below the HIPC sustainability thresholds (Figure 1).

\section{Conclusions}

39. Debt relief expected at the completion point will help Ghana reach debt sustainability, provided the country follows sound economic policies. The updated debt sustainability analysis shows that the amount of debt relief estimated at the decision point will be sufficient to bring the country's debt burden indicators to manageable levels and keep them on a sustainable path during the next 20 years.

40. The sensitivity analysis shows that, after completion point, Ghana's debt sustainability would be robust to moderate country-specific shocks, even of a persistent nature. However, the scenarios also suggest that if Ghana were affected by permanent adverse shocks, or a combination of shocks, debt sustainability could once again be compromised.

41. Policy implementation by the Ghanaian authorities since the decision point has been generally satisfactory. All but one of the completion point triggers were observed. The condition that was not met - i.e., that relating to petroleum pricing - signals an important weakness in structural policies over the past two years. But the staffs believe that the fundamental reform of petroleum pricing to which the authorities have committed will, by removing government altogether from the price-setting process, address the root cause of past problems. Because of the impending elections, implementation of this reform was deemed infeasible before early 2005, raising the issue as to whether the completion point should have been delayed until the new regime was in place. The staffs considered that the roughly one year's delay that would have been required in this case was disproportionate in light of the otherwise strong policy performance, and given that implementation of the new pricing regime has been established as a strict condition for the completion of the third review under the PRGF arrangement with the Fund. 


\section{ISSUES FOR DISCUSSION}

The staff seeks guidance from Directors on the following points:

- Do Directors agree that Ghana should reach the completion point at this time? Do Directors agree that the authorities' stated commitment to a new petroleum pricing regime provides a sufficient budgetary safeguard against rising world oil prices, and hence warrants a waiver of the related completion point trigger that was not observed?

- Do Directors agree that sufficient assurances have been given by Ghana's other creditors to commit enhanced HIPC Initiative resources to Ghana, as approved at the decision point, on an irrevocable basis?

- $\quad$ Do Directors agree that Ghana's poverty reduction strategy and expenditure-tracking system provide a satisfactory basis for ensuring that enhanced HIPC Initiative assistance and other resources will continue to promote poverty reduction? 


\section{Ghana: Debt Management Assessment}

\section{A. Introduction}

1. Responsibility for external debt management resides in the Aid and Debt Management Unit (ADMU) of the Ministry of Finance and Economic Planning (MOEFP), with other divisions in the ministry concerned with negotiating and contracting external public- and publicly-guaranteed debt. ADMU maintains the debt database and ensures prompt servicing of external obligations. While ADMU does not prepare independent reports on debt, it does provide key inputs on debt and debt service obligations to the Bank of Ghana (BOG) for its various reports, to the Controller and Accountant General's office, and to other government agencies requiring this information. Since 2003, ADMU has established a system to track and record grant flows to Ghana, given their importance in overall aid flows. Information on project and program grants is received from donors on a quarterly basis. ADMU chairs the Aid and Debt Sub-Committee, which meets periodically to discuss policy issues related to external debt management.

2. At the time of decision point, ADMU maintained data relating to central government or government-guaranteed debt, but had little information on loans made to public enterprises where there was no explicit government guarantee. Recently, state-owned enterprises have started seeking approval from MOFEP before contracting external debt, even if a formal guarantee is not required. Creditors also tend to inform the MOFEP before negotiating such credits. ADMU maintains a record of such debt when it is signed. The Bank of Ghana and MOFEP are jointly responsible for the technical work relating to the granting of state guarantees.

3. While ADMU's focus has been external debt, the agency has also made attempts to track domestic debt, which until recently, was exclusively the purview of the Bank of Ghana. (MOFEP received technical assistance from the US, which has focused on enhancing the reporting of domestic debt, as well as on strengthening cash management and forecasting systems. Japan has provided technical assistance for external debt management.)

\section{B. Debt Recording and Reporting}

4. Ghana has used the Commonwealth Secretariat's database system, CS-DRMS since 1989, and sufficient staff have been trained and are proficient in its use. The database is accurate in the case of multilateral debt, on which information regarding payments falling due and payments made, are regularly updated by ADMU's staff. In the case of bilateral debt, gaps have appeared in the recording of debt service charges as a result of Paris Club agreements. 


\section{Debt Management and Borrowing Strategy}

5. New borrowing must be strictly limited to concessional loans with a grant element of 35 percent or more. This policy covers government and parastatal loans with a government guarantee. ADMU is the only government entity authorized to contract or guarantee external debt. Training on the legal aspects of debt management has been provided with the help of UNITAR (United Nations Institute for Training and Research). While ADMU coordinates with BOG with respect to maintaining the database, there is need for further coordination with respect to a forward-looking borrowing strategy, which is based on a common view of the macroeconomic outlook.

\section{Analytical Capacity}

6. While the technical staff of ADMU are experienced in handling the day-to-day issues of debt management, awareness of debt restructuring options and sustainability analyses tends to be concentrated in a few individuals. Progress is being made with training in the software Debt-Pro, but there is a need for further technical assistance both to ensure a wider dispersion of the skills of debt sustainability analyses throughout the staff, and to assist in integrating debt simulations with macroeconomic projections. ADMU is preparing a policy paper on post-HIPC debt sustainability which it plans to share with key policymakers shortly. 
Table 1. Ghana: Selected Economic and Financial Indicators, 2001-23

\begin{tabular}{|c|c|c|c|c|c|c|c|c|c|c|}
\hline & 2001 & 2002 & $\begin{array}{r}2003 \\
\text { Est. }\end{array}$ & $\begin{array}{l}2004 \\
\text { Prog. }\end{array}$ & $\begin{array}{l}2005 \\
\text { Proj. }\end{array}$ & $\begin{array}{l}2006 \\
\text { Proj. }\end{array}$ & $\begin{array}{l}2007 \\
\text { Proj. }\end{array}$ & $\begin{array}{l}2008 \\
\text { Proj. }\end{array}$ & $\begin{array}{r}2009-2015 \\
\text { Average }\end{array}$ & $\begin{array}{r}2016-2023 \\
\text { Average }\end{array}$ \\
\hline \multicolumn{11}{|c|}{ (Annual percentage change, unless otherwise specified) } \\
\hline National income and prices & & & & & & & & & & \\
\hline Real GDP & 4.2 & 4.5 & 5.2 & 5.2 & 5.0 & 5.0 & 5.0 & 5.0 & 5.0 & 5.0 \\
\hline Consumer price index (annual average) & 32.9 & 14.8 & 26.7 & 10.8 & 6.0 & 5.0 & 5.0 & 5.0 & 5.0 & 5.0 \\
\hline \multicolumn{11}{|l|}{ External sector } \\
\hline Exports, f.o.b. & -3.6 & 10.2 & 20.1 & 8.1 & 7.0 & 6.2 & 3.9 & 4.3 & 5.3 & 5.4 \\
\hline Imports, f.o.b. & 2.6 & -4.1 & 20.1 & 11.0 & 8.5 & 6.1 & 4.4 & 4.9 & 5.7 & 5.5 \\
\hline Export volume & -1.3 & -2.1 & -6.8 & 10.8 & 6.2 & 6.3 & 3.4 & 3.4 & 3.7 & 3.8 \\
\hline Import volume & 10.0 & -6.8 & 6.9 & 5.7 & 11.4 & 6.6 & 4.1 & 4.5 & 4.7 & 4.5 \\
\hline Terms of trade & 4.8 & 9.4 & 14.8 & -7.0 & 3.3 & 0.4 & 0.2 & 0.5 & 0.6 & 0.6 \\
\hline \multicolumn{11}{|l|}{ Government budget } \\
\hline Domestic revenue (excluding grants) & 43.5 & 27.5 & 56.2 & 32.3 & 13.6 & 9.9 & 10.9 & 9.8 & 10.6 & 11.5 \\
\hline Total expenditure & 65.5 & 2.4 & 50.2 & 17.5 & 4.4 & 7.2 & 9.8 & 8.2 & 10.5 & 11.0 \\
\hline Current expenditure & 50.5 & 28.8 & 35.7 & 15.1 & -5.5 & 4.9 & 9.0 & 8.3 & 10.5 & 11.0 \\
\hline Capital expenditure and net lending & 95.7 & -38.7 & 98.4 & 22.3 & 25.2 & 10.9 & 10.9 & 8.1 & 10.5 & 11.4 \\
\hline \multicolumn{11}{|l|}{ Money and credit } \\
\hline Net domestic assets $1 /$ & 13.5 & 22.9 & -18.6 & 2.4 & 1.1 & $\ldots$ & $\ldots$ & $\ldots$ & $\ldots$ & $\ldots$ \\
\hline Broad money (excluding foreign currency deposits) & 48.4 & 49.6 & 40.9 & 19.2 & 13.0 & $\ldots$ & $\ldots$ & $\ldots$ & $\ldots$ & $\ldots$ \\
\hline Reserve money (excluding foreign currency deposits) & 31.3 & 42.6 & 33.4 & 20.5 & 12.9 & $\ldots$ & $\ldots$ & $\ldots$ & $\ldots$ & $\ldots$ \\
\hline \multirow[t]{2}{*}{ Velocity (GDP/end-of-period broad money) } & 4.8 & 4.1 & 4.0 & 4.0 & 4.0 & $\cdots$ & $\cdots$ & $\cdots$ & $\cdots$ & $\cdots$ \\
\hline & \multicolumn{10}{|c|}{ (In percent of GDP, unless otherwise specified) } \\
\hline Investment and saving & & & & & & & & & & \\
\hline Gross investment & 26.6 & 19.7 & 23.2 & 23.1 & 23.8 & 24.0 & 24.1 & 24.2 & 24.7 & 26.6 \\
\hline Gross national saving & 21.3 & 20.2 & 24.9 & 23.5 & 23.3 & 23.8 & 23.8 & 23.8 & 23.3 & 24.7 \\
\hline \multicolumn{11}{|l|}{ Government budget } \\
\hline Total revenue & 18.1 & 18.0 & 20.8 & 23.1 & 23.2 & 22.9 & 22.8 & 22.4 & 21.7 & 21.1 \\
\hline Grants & 6.9 & 3.1 & 4.7 & 4.3 & 3.5 & 3.2 & 2.9 & 2.7 & 1.9 & 1.3 \\
\hline Total expenditure & 32.7 & 26.1 & 29.0 & 28.6 & 26.3 & 25.4 & 25.0 & 24.3 & 23.4 & 22.3 \\
\hline Overall balance (including grants) 2/ & -9.0 & -6.8 & -4.5 & -1.6 & -0.9 & -0.6 & -0.4 & -0.7 & -1.5 & -1.8 \\
\hline Domestic primary balance & 3.8 & 2.0 & 2.2 & 1.6 & 1.8 & 1.2 & 1.3 & 0.9 & 1.6 & 1.6 \\
\hline \multicolumn{11}{|l|}{ External sector } \\
\hline \multirow[t]{2}{*}{ Current account balance 3 / } & -5.3 & 0.5 & 1.7 & 0.3 & -1.0 & -1.0 & -1.0 & -1.1 & -1.9 & -2.0 \\
\hline & \multicolumn{10}{|c|}{ (In millions of U.S. dollars, unless otherwise specified) } \\
\hline Gross international reserves (end of period) & 344 & 635 & 1427 & 1541 & 1747 & 1972 & 2106 & 2232 & 2953 & 4919 \\
\hline (in months of imports of goods and services) & 1.2 & 1.9 & 3.9 & 3.9 & 4.2 & 4.5 & 4.6 & 4.6 & 5.0 & 5.7 \\
\hline
\end{tabular}


Table 2. Ghana: Balance of Payments, 2000-2023

(In millions of U.S. dollars, unless otherwise specified)

\begin{tabular}{|c|c|c|c|c|c|c|c|c|c|c|c|c|}
\hline & 2000 & 2001 & $\begin{array}{l}2002 \\
\text { Prel }\end{array}$ & 2003 & 2003 & 2004 & 2005 & 2006 & 2007 & 2008 & 2009-15 & $\begin{array}{l}2016-23 \\
\text { Average }\end{array}$ \\
\hline Exports f.o.b. & 1,936 & 1,867 & $\frac{c^{\text {Prel. }}}{2,057}$ & $\begin{array}{l}\text { Prov. } \\
2,277\end{array}$ & PTOV. & $\frac{\text { Proj. }}{2,672}$ & $\frac{{ }^{2} \text { PTOJ. }}{2,859}$ & $\begin{array}{l}\text { Proj. } \\
3,035\end{array}$ & $\begin{array}{c}\text { Proj. } \\
3,153\end{array}$ & $\begin{array}{c}\text { Proj. } \\
3,288\end{array}$ & $\begin{array}{r}\text { Average } \\
4,063\end{array}$ & $\frac{\text { Average }}{6,013}$ \\
\hline Cocoa beans and cocoa products & 437 & 381 & 463 & 772 & 818 & 927 & 904 & 925 & 952 & 980 & 1,154 & 1,560 \\
\hline Gold & 705 & 618 & 689 & 770 & 830 & 929 & 1,037 & 1,076 & 1,120 & 1,167 & 1,483 & 2,301 \\
\hline Timber and timber products & 175 & 169 & 182 & 176 & 174 & 184 & 196 & 214 & 233 & 247 & 314 & 488 \\
\hline Others & 619 & 699 & 723 & 560 & 649 & 632 & 722 & 821 & 848 & 894 & 1,112 & 1,665 \\
\hline Imports, f.o.b. & $-2,759$ & $-2,831$ & $-2,714$ & $-3,189$ & $-3,259$ & $-3,617$ & $-3,925$ & $-4,165$ & $-4,348$ & $-4,561$ & $-5,741$ & $-8,589$ \\
\hline Non-oil & $-2,239$ & $-2,314$ & $-2,206$ & $-2,582$ & $-2,696$ & $-2,955$ & $-3,277$ & $-3,510$ & $-3,673$ & $-3,866$ & $-4,819$ & $-7,041$ \\
\hline Oil & -520 & -517 & -508 & -608 & -563 & -662 & -648 & -655 & -675 & -694 & -922 & $-1,547$ \\
\hline Trade balance & -823 & -964 & -657 & -912 & -788 & -944 & $-1,066$ & $-1,130$ & $-1,195$ & $-1,273$ & $-1,678$ & $-2,575$ \\
\hline Services (net) & -246 & -182 & -214 & -285 & -280 & -304 & -314 & -307 & -300 & -300 & -310 & -405 \\
\hline Of which: interest payments & -109 & -106 & -124 & -119 & -110 & -124 & -118 & -112 & -108 & -105 & -116 & -155 \\
\hline Private transfers (net) & 496 & 600 & 680 & 783 & 801 & 875 & 932 & 990 & 1,040 & 1,093 & 1,336 & 1,933 \\
\hline \multicolumn{13}{|l|}{ Current account balance, } \\
\hline Official transfers (net) & 154 & 263 & 221 & 385 & 393 & 401 & 369 & 359 & 361 & 367 & $\begin{array}{r}-052 \\
380\end{array}$ & $\begin{array}{r}-1,047 \\
533\end{array}$ \\
\hline Of which:HIPC grants & 0 & 0 & 62 & 79 & 81 & 113 & 122 & 113 & 122 & 115 & 90 & 68 \\
\hline \multicolumn{13}{|l|}{ Current account balance, } \\
\hline $\begin{array}{l}\text { Including official transfers } \\
\text { Capital account }\end{array}$ & $\begin{array}{r}-419 \\
163\end{array}$ & $\begin{array}{r}-283 \\
192\end{array}$ & $\begin{array}{r}30 \\
-65\end{array}$ & $\begin{array}{l}-28 \\
129\end{array}$ & $\begin{array}{l}127 \\
161\end{array}$ & $\begin{array}{l}29 \\
43\end{array}$ & $\begin{array}{r}-79 \\
89\end{array}$ & $\begin{array}{r}-88 \\
116\end{array}$ & $\begin{array}{r}-94 \\
154\end{array}$ & $\begin{array}{r}-113 \\
196\end{array}$ & $\begin{array}{r}-272 \\
403\end{array}$ & $\begin{array}{r}-514 \\
809\end{array}$ \\
\hline Official capital (net) & 97 & 104 & -115 & 54 & 86 & -26 & 31 & 55 & 89 & 126 & 270 & 537 \\
\hline \multicolumn{13}{|l|}{ Medium and Long-term loans } \\
\hline Inflows & 513 & 391 & 195 & 337 & 370 & 319 & 359 & 359 & 366 & 393 & 512 & 838 \\
\hline Amortization & -416 & -288 & -309 & -283 & -284 & -345 & -327 & -304 & -277 & -267 & -242 & -301 \\
\hline Private capital & 65 & 88 & 50 & 75 & 75 & 69 & 57 & 61 & 66 & 70 & 133 & 273 \\
\hline Other capital and errors and omissions & 134 & 107 & 75 & 101 & 214 & -205 & -62 & -44 & -35 & -37 & 0 & 0 \\
\hline Overall balance & -123 & 17 & 40 & 202 & 502 & -134 & -53 & -15 & 25 & 46 & 131 & 295 \\
\hline Change in arrears & 27 & 34 & -61 & 0 & 0 & 0 & 0 & 0 & 0 & 0 & 0 & 0 \\
\hline Financing & 96 & -50 & 21 & -202 & -502 & 134 & 53 & 15 & -25 & -46 & -131 & -295 \\
\hline Debt deferral & 0 & 150 & -35 & -35 & -35 & -35 & -35 & -35 & 0 & 0 & 0 & 0 \\
\hline Net international reserves (negative is increase) 1 / & 96 & -200 & -158 & -378 & -675 & -100 & -181 & -188 & -196 & -192 & -232 & -336 \\
\hline Of which: Use of Fund credit & -2 & 1 & 54 & 52 & 53 & -5 & 24 & 37 & -61 & -67 & -38 & -14 \\
\hline Disbursements (PRGF) & 35 & 67 & 68 & 73 & 74 & 39 & 78 & 78 & 0 & 0 & 0 & 0 \\
\hline Repayments (PRGF) & -37 & -66 & -14 & -21 & -21 & -44 & -54 & -41 & -61 & -67 & -38 & -14 \\
\hline Change in reserves (negative is increase) & 52 & -79 & -292 & -460 & -792 & -114 & -206 & -225 & -135 & -126 & -193 & -322 \\
\hline Exceptional financing 2/ & 0 & 0 & 214 & 212 & 208 & 269 & 269 & 238 & 170 & 146 & 100 & 41 \\
\hline \multicolumn{13}{|l|}{ Memorandum items: } \\
\hline \multicolumn{13}{|l|}{ Gross international reserves } \\
\hline End of period (US\$ millions) & 264 & 344 & 635 & 1095 & 1,427 & 1,541 & 1,747 & 1,972 & 2,106 & 2,232 & 2,953 & 4,919 \\
\hline In months of imports of goods and services & 0.9 & 1.2 & 2.0 & 3.2 & 3.9 & 3.9 & 4.2 & 4.5 & 4.6 & 4.6 & 4.9 & 5.6 \\
\hline \multicolumn{13}{|l|}{ Cocoa exports } \\
\hline Volume (in thousands of tons) & 389 & 370 & 367 & 468 & 403 & 560 & 560 & 566 & 583 & 600 & 677 & 845 \\
\hline Price (in US\$ per ton) & 1,092 & 1,021 & 1,266 & 1,650 & 1,950 & 1,650 & 1,600 & 1,620 & 1,610 & 1,605 & 1,694 & 1,843 \\
\hline
\end{tabular}

Sources: Bank of Ghana; and Fund staff estimates and projections.

1/ Definition changed from Net Foreign Assets to Net International Reserves at the end of 2000.

2/ Includes interim HIPC relief from Paris Club creditors comprising Naples and Cologne flow terms. 
Table 3. Ghana: Central Government Budgetary Operations and Financing, 2000-2023 1/

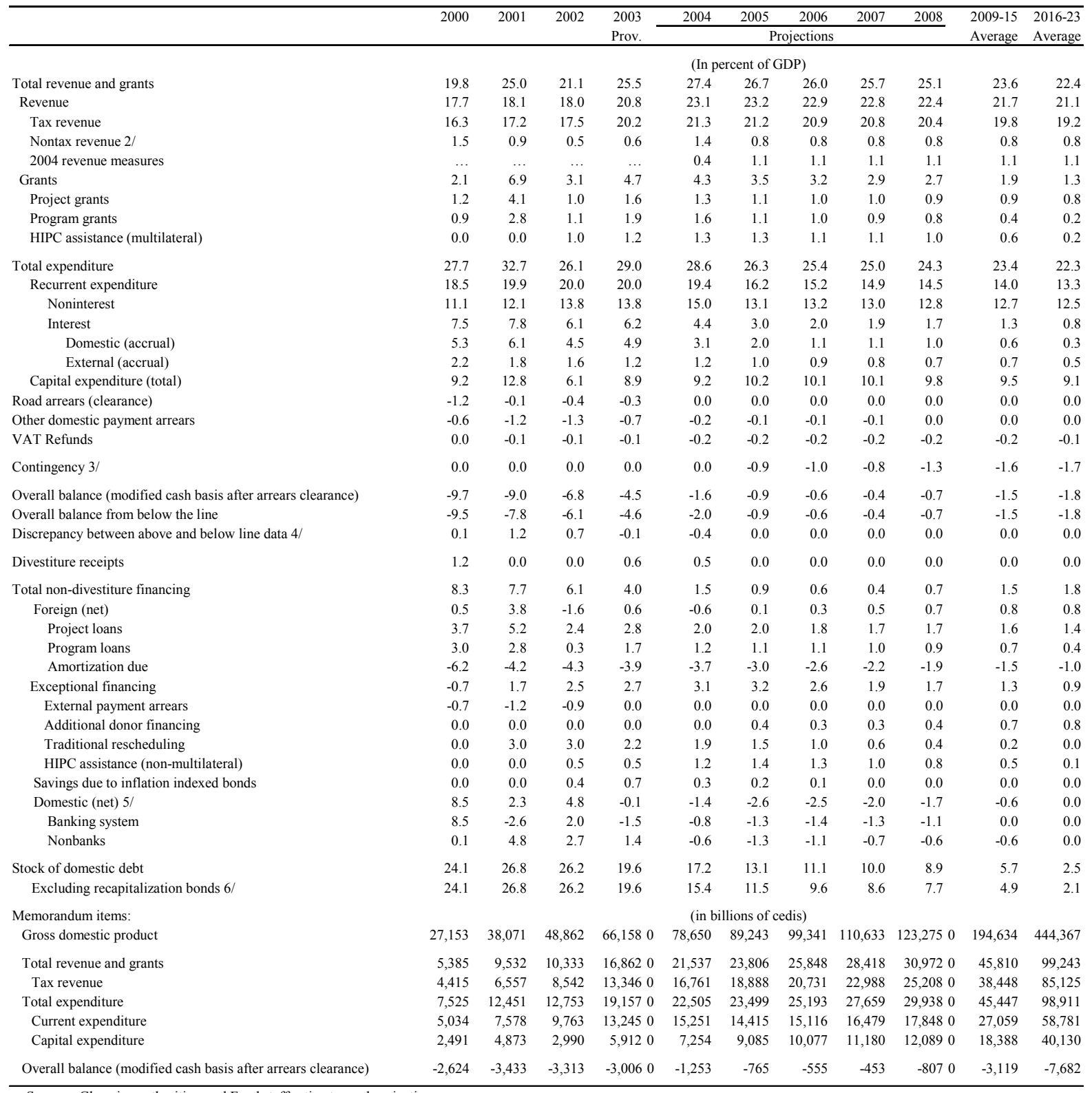

Sources: Ghanaian authorities; and Fund staff estimates and projections.

1/ From 2001 onward, above-the-line data for domestic recurrent and capital expenditure are presented on a cash basis (payment vouchers); arrears not reflected in line expenditures.

2/ Prior to 2002, nontax revenue included positive balances on committed accounts outside the consolidated fund.

3/ Indicates scope for additional expenditure and tax cuts (if negative) or expenditure cuts and tax increases (if positive).

4/ Projected discrepancy in 2004 reflects float.

5/ Domestic debt stock estimates exclude non-interest bearing perpetual BoG revaluation stocks.

6/ In 2004 for BOG and Tema Oil Refinery. 
Table 4. Ghana: HIPC Initiative-Assistance Under a Proportional Burden-Sharing Approach 1/ 2/ (In millions of U.S. dollars, unless otherwise indicated)

\begin{tabular}{|c|c|c|c|c|}
\hline \multirow{2}{*}{$\begin{array}{l}\text { NPV of debt- } \\
\text { to-revenue-target } \\
\text { (in percent) } \\
250\end{array}$} & \multicolumn{3}{|c|}{ (In NPV terms at end 2000) } & $\begin{array}{c}\text { Common } \\
\text { Reduction Factor } \\
4 / \\
\text { (Percent) } \\
\end{array}$ \\
\hline & 2,186 & 1,084 & 1,102 & 56.2 \\
\hline \multicolumn{5}{|l|}{ Memorandum items: } \\
\hline NPV of debt $5 /$ & 3,893 & 1,931 & 1,962 & \\
\hline Paris Club Creditors & 1,473 & & & \\
\hline Non-Paris Club Creditors & 60 & & & \\
\hline Commercial Creditors & 398 & & & \\
\hline Central government revenues $6 /$ & 683 & & & \\
\hline NPV of debt-to-revenue ratio (Percent) & 570 & & & \\
\hline
\end{tabular}

Sources: Ghanaian authorities and staff estimates and projections.

1/ The proportional burden sharing approach is described in "HIPC Initiative--Estimated Costs and Burden Sharing Approaches" (EBS/97/127, 7/7/97 and IDA/SEC M 97-306, 7/7/97).

2/ Includes a hypothetical stock-of-debt operation on Naples terms (December 2000) and comparable treatment by other official bilateral creditors.

3/ Includes official bilateral creditors and commercial debt.

4/ Each creditor's NPV reduction in percent of its exposure at the decision point.

5/ Based on end-2000 data after full application of traditional debt relief mechanisms.

6/ Excludes grants. 
Table 5. Comparison of Discount Rate and Exchange Rate Assumptions at end-2000 and end-2003

\begin{tabular}{|c|c|c|c|c|}
\hline & \multicolumn{2}{|c|}{$\begin{array}{l}\text { Discount Rates 1/ 2/ } \\
\text { (In percent per annum) }\end{array}$} & \multicolumn{2}{|c|}{$\begin{array}{c}\text { Exchange Rates } \\
\text { (Currency per U.S. dollar) }\end{array}$} \\
\hline & $\begin{array}{r}\text { At } \\
\text { Decision } \\
\text { point }\end{array}$ & $\begin{array}{r}\text { At } \\
\text { Completion } \\
\text { point }\end{array}$ & $\begin{array}{r}\text { At Decision } \\
\text { Point }\end{array}$ & $\begin{array}{r}\text { At } \\
\text { Completion } \\
\text { Point }\end{array}$ \\
\hline \multicolumn{5}{|l|}{ Currency } \\
\hline Austrian Shillings & 6.25 & 4.63 & 14.79 & 10.89 \\
\hline Belgian Franc & 6.25 & 4.63 & 43.35 & 31.94 \\
\hline Canadian Dollar & 7.00 & 5.18 & 1.50 & 1.29 \\
\hline Chinese Yuan & 6.09 & 4.20 & 8.28 & 8.28 \\
\hline Danish Kroner & 6.73 & 4.77 & 8.02 & 5.96 \\
\hline Deutsche Mark & 6.25 & 4.63 & 2.10 & 1.55 \\
\hline Euro & 6.25 & 4.63 & 1.07 & 0.79 \\
\hline Finnish Markaa & 6.25 & 4.63 & 6.39 & 4.71 \\
\hline French Franc & 6.25 & 4.63 & 7.05 & 5.19 \\
\hline Great Britain Sterling & 6.73 & 5.37 & 0.67 & 0.56 \\
\hline Irish Punt & 6.25 & 4.63 & 0.85 & 0.62 \\
\hline Italian Lira & 6.25 & 4.63 & 2080.89 & 1533.07 \\
\hline Japanese Yen & 2.03 & 1.70 & 114.90 & 107.10 \\
\hline Korean Won & 9.41 & 5.74 & 1264.50 & 1192.60 \\
\hline Kuwaiti Dinar & 6.09 & 4.47 & 0.31 & 0.29 \\
\hline Netherland Guilders & 6.25 & 4.63 & 2.37 & 1.74 \\
\hline Norwegian Kroner & 8.02 & 5.30 & 8.85 & 6.68 \\
\hline Portugese Escudo & 6.25 & 4.63 & 215.46 & 158.73 \\
\hline Saudi Arabian Ryal & 6.09 & 4.20 & 3.75 & 3.75 \\
\hline South African Rand & 6.09 & 4.20 & 7.57 & 6.64 \\
\hline Spanish Peseta & 6.25 & 4.63 & 178.81 & 131.74 \\
\hline Special Drawing Rights & 6.09 & 4.20 & 0.77 & 0.67 \\
\hline Swedish Kroner & 6.20 & 5.00 & 9.54 & 7.19 \\
\hline Swiss Franc & 5.33 & 3.21 & 1.64 & 1.24 \\
\hline United States Dollar & 7.19 & 4.47 & 1.00 & 1.00 \\
\hline $\begin{array}{l}\text { Memorandum item: } \\
\text { Paris Club cutoff date is January } 1,1983 .\end{array}$ & & & & \\
\hline
\end{tabular}

Sources: OECD; and IMF, International Financial Statistics.

1/ The discount rates used are the average commercial interest reference rates (CIRRs) for the respective currencies over the six-month period ending in December 2003 for the completion point and 2/ For all Euro area currencies, the Euro CIRR is used. For the Kuwaiti Dinar, the US dollar CIRR is used for completion point calculations (compared to the decision point calculations, when the SDR CIRR was used), in accordance to the explicit peg of the Dinar to the US dollar in the beginning of 2003. For all other currencies for which the respective CIRRs are not available, the SDR discount rate is used as a proxy. 
Table 6. Ghana: Comparison of Net Present Value of External Public Debt Between Decision Point and Completion Point (In millions of U.S. dollars; unless otherwise indicated)

\begin{tabular}{|c|c|c|c|c|c|c|c|}
\hline & \multirow{2}{*}{\multicolumn{2}{|c|}{$\begin{array}{c}\text { Stock at end-2000 } \\
\text { Decision Point DSA 1/ }\end{array}$}} & \multicolumn{5}{|c|}{ Stock at end-2003 } \\
\hline & & & \multicolumn{2}{|c|}{ Decision Point DSA (Proj.) 1/ } & \multicolumn{3}{|c|}{ Completion Point DSA 2/ } \\
\hline & $\begin{array}{r}\text { After } \\
\text { traditional } \\
\text { debt relief }\end{array}$ & $\begin{array}{r}\text { After } \\
\text { enhanced } \\
\text { debt relief }\end{array}$ & $\begin{array}{r}\text { After } \\
\text { traditional } \\
\text { debt relief }\end{array}$ & $\begin{array}{r}\text { After } \\
\text { enhanced } \\
\text { debt relief }\end{array}$ & $\begin{array}{r}\text { After traditional } \\
\text { debt relief }\end{array}$ & $\begin{array}{r}\text { After enhanced } \\
\text { debt relief }\end{array}$ & $\begin{array}{r}\text { After additional } \\
\text { bilateral relief 3/ }\end{array}$ \\
\hline NPV of debt using end-2000 parameters & 3,893 & 1,706 & 3,889 & 2,154 & 3,782 & 2,017 & 1,575 \\
\hline Multilateral & 1,962 & 860 & 2,546 & 1,502 & 2,341 & 1,292 & 1,292 \\
\hline Official bilateral and commercial & 1,931 & 846 & 1,343 & 653 & 1,440 & 724 & 283 \\
\hline NPV of debt using end-2003 parameters & $\ldots$ & $\ldots$ & $\ldots$ & $\ldots$ & 5,000 & 2,937 & 2,370 \\
\hline Multilateral & $\ldots$ & $\ldots$ & $\ldots$ & $\ldots$ & 3,277 & 2,042 & 2,042 \\
\hline Official bilateral and commercial & $\ldots$ & $\ldots$ & $\ldots$ & $\ldots$ & 1,723 & 895 & 327 \\
\hline \multicolumn{8}{|l|}{ NPV of debt-to-revenues ratio 4/ } \\
\hline Using end-2000 parameters & 570 & 250 & 319 & 177 & $\ldots$ & $\ldots$ & \\
\hline Using end-2003 parameters & $\ldots$ & $\ldots$ & & & 321 & 189 & 152 \\
\hline \multicolumn{8}{|l|}{ Memorandum items: } \\
\hline \multicolumn{8}{|l|}{ NPV of enhanced HIPC assistance 5/ } \\
\hline Using end-2000 parameters & $\ldots$ & 2,186 & & & $\ldots$ & $\ldots$ & $\ldots$ \\
\hline Using end-2003 parameters & $\cdots$ & $\ldots$ & & & $\ldots$ & 2,063 & $\ldots$ \\
\hline \multicolumn{8}{|l|}{ Central government revenues 6/ } \\
\hline Decision point & 683 & 683 & 1,218 & 1,218 & $\ldots$ & .. & $\ldots$ \\
\hline Completion point & $\ldots$ & $\ldots$ & & & 1,555 & 1,555 & 1,555 \\
\hline
\end{tabular}

1/ Based on stock of debt reconciled as of end-December 2000, assuming full (hypothetical) delivery of enhanced HIPC assistance.

2/ Based on stock of debt reconciled as of end-December 2003, assuming full (hypothetical) delivery of enhanced HIPC assistance.

3/ After debt relief beyond HIPC offered by some of the Paris Club creditors on a voluntary basis.

4 / Revenue is defined as central government revenue, excluding grants.

5/ The value of assistance under the enhanced HIPC framework was determined at decision point using end-2000 parameters (exchange rates and discount factors). The corresponding values for enhanced HIPC relief expressed as of end-2003 are provided for information only.

6/ Excludes grants. 
Table 7. Ghana: Nominal and Net Present Value of External Debt at Completion Point, End-2003 1/

(in millions of US dollars)

\begin{tabular}{|c|c|c|c|c|}
\hline \multirow[b]{3}{*}{ Total } & \multicolumn{2}{|c|}{ Legal Situation 2/ } & \multicolumn{2}{|c|}{ After Full Application of Traditional Debt Relief 3/ } \\
\hline & Nominal Debt & NPV of Debt & Nominal Debt & NPV of Debt \\
\hline & $7,548.9$ & $5,541.6$ & $7,033.3$ & $5,032.1$ \\
\hline Multilateral & $5,176.1$ & $3,277.0$ & $5,176.1$ & $3,277.0$ \\
\hline IDA & $3,964.6$ & $2,376.5$ & $3,964.6$ & $2,376.5$ \\
\hline IBRD & 3.9 & 4.0 & 3.9 & 4.0 \\
\hline African Development Bank Group & 500.8 & 324.8 & 500.8 & 324.8 \\
\hline IMF & 453.1 & 381.2 & 453.1 & 381.2 \\
\hline BADEA & 23.4 & 21.9 & 23.4 & 21.9 \\
\hline European Investment Bank & 50.9 & 48.7 & 50.9 & 48.7 \\
\hline European Union & 36.1 & 27.5 & 36.1 & 27.5 \\
\hline IFAD & 92.1 & 56.6 & 92.1 & 56.6 \\
\hline Nordic Development Bank & 33.4 & 19.4 & 33.4 & 19.4 \\
\hline OPEC & 17.7 & 16.4 & 17.7 & 16.4 \\
\hline Official bilateral & $2,106.0$ & $1,967.4$ & $1,656.0$ & $1,539.2$ \\
\hline Paris Club & $1,976.3$ & $1,869.6$ & $1,552.1$ & $1,458.2$ \\
\hline Austria & 70.7 & 52.4 & 55.1 & 47.1 \\
\hline Belgium & 3.6 & 3.0 & 1.0 & 0.8 \\
\hline Canada & 3.2 & 3.0 & 11.7 & 12.0 \\
\hline Finland & 2.5 & 2.9 & 2.1 & 2.1 \\
\hline France & 143.1 & 124.5 & 121.8 & 106.1 \\
\hline Germany & 249.7 & 144.0 & 217.3 & 128.2 \\
\hline Italy & 50.6 & 44.4 & 26.9 & 24.7 \\
\hline Japan & $1,057.9$ & $1,112.1$ & 817.8 & 868.7 \\
\hline Netherlands & 92.2 & 94.4 & 80.0 & 79.2 \\
\hline Norway & 7.3 & 7.0 & 7.3 & 7.1 \\
\hline Spain & 64.9 & 48.5 & 59.3 & 44.6 \\
\hline Sweden & 40.5 & 34.3 & 24.7 & 21.6 \\
\hline United Kingdom & 103.5 & 105.5 & 100.3 & 86.9 \\
\hline United States & 86.6 & 93.5 & 26.8 & 29.0 \\
\hline Other official bilateral & 129.7 & 97.8 & 103.9 & 81.0 \\
\hline China & 64.6 & 55.9 & 55.0 & 41.1 \\
\hline Kuwaiti Fund & 32.9 & 19.4 & 17.9 & 17.1 \\
\hline Korea & 25.0 & 18.0 & 20.4 & 13.7 \\
\hline Saudi Fund & 7.3 & 4.5 & 10.6 & 9.0 \\
\hline Commercial creditors 4/ & 266.8 & 297.2 & 201.3 & 216.0 \\
\hline Germany & 3.3 & 3.2 & 7.9 & 7.8 \\
\hline Korea (Samsung Corp.) & 152.5 & 182.0 & 99.9 & 118.0 \\
\hline United Kingdom & 47.0 & 45.1 & 30.2 & 28.2 \\
\hline United States & 19.5 & 20.2 & 8.3 & 8.4 \\
\hline South Africa & 42.7 & 44.8 & 29.5 & 30.8 \\
\hline Others & 1.9 & 1.9 & 25.5 & 22.7 \\
\hline
\end{tabular}

Sources: Ghanaian authorities; and staff estimates.

1/ Figures are based on data as of December 31, 2003.

2/ Reflects the external debt situation as of end-2003, including a Paris Club flow rescheduling on Cologne terms. Since most of Ghana's contracted after the original cut-off debt of January 1, 1983, the Paris Club fixed a new cut-off debt of June 20, 1999 to deliver interim assistance and recalculate burden sharing amongst its members.

3/ After full use of traditional debt relief mechanisms including for non-Paris Club members, using the original cut-off date of 1983.

4/ Several commercial creditors belonging to France, Belgium, Netherlands, the United Kingdom and Japan are

now classified as bilateral debt, as a result of their debt being included in Paris Club agreements. 
Table 8. Ghana: External Debt Service After Full Implementation of Debt-Relief Mechanisms, 2004-2023 (In millions of U.S. dollars)

\begin{tabular}{|c|c|c|c|c|c|c|c|c|c|c|c|c|c|c|c|c|c|c|c|c|c|c|}
\hline & 2004 & 2005 & 2006 & 2007 & 2008 & 2009 & 2010 & 2011 & 2012 & 2013 & 2014 & 2015 & 2016 & 2017 & 2018 & 2019 & 2020 & 2021 & 2022 & 2023 & \multicolumn{2}{|c|}{$\frac{2004-13 \quad 2014-23}{\text { Averages }}$} \\
\hline \multirow{2}{*}{\multicolumn{23}{|c|}{$\begin{array}{l}\text { I. After traditional debt-relief mechanisms } \\
\text { (incl. new debt) } 1\end{array}$}} \\
\hline $\begin{array}{l}\text { (incl. new debt) } 1 / \\
\text { Existing debt }\end{array}$ & $\begin{array}{l}469.8 \\
464.3\end{array}$ & $\begin{array}{l}486.9 \\
475.5\end{array}$ & $\begin{array}{l}451.3 \\
433.9\end{array}$ & $\begin{array}{l}433.1 \\
409.4\end{array}$ & $\begin{array}{l}409.9 \\
3796\end{array}$ & $\begin{array}{l}378.9 \\
341.4\end{array}$ & $\begin{array}{l}374.3 \\
321.1\end{array}$ & $\begin{array}{l}396.3 \\
319.2\end{array}$ & $\begin{array}{l}403.4 \\
302.4\end{array}$ & $\begin{array}{l}393.6 \\
283.7\end{array}$ & $\begin{array}{l}384.0 \\
264.5\end{array}$ & $\begin{array}{l}395.6 \\
258.9\end{array}$ & $\begin{array}{l}404.7 \\
256.5\end{array}$ & $\begin{array}{l}412.6 \\
252.7\end{array}$ & $\begin{array}{l}\begin{array}{l}437.6 \\
249.8\end{array} \\
\end{array}$ & $\begin{array}{l}461.1 \\
243.8\end{array}$ & & 514.1 & 542.6 & 577.7 & 419.8 & $\begin{array}{l}461.2 \\
243.3\end{array}$ \\
\hline $\begin{array}{l}\text { Existing debt } \\
\text { Multilateral }\end{array}$ & $\begin{array}{l}484.3 \\
185.5\end{array}$ & 201.9 & 194.0 & 215.7 & 227.1 & 208.2 & 201.7 & 210.4 & 195.8 & 186.2 & $\begin{array}{l}204.5 \\
176.3\end{array}$ & 179.0 & $\begin{array}{l}256.5 \\
181.3\end{array}$ & $\begin{array}{l}252.1 \\
183.6\end{array}$ & $\begin{array}{l}249.8 \\
183.3\end{array}$ & $\begin{array}{l}243.8 \\
185.0\end{array}$ & $\begin{array}{l}233.4 \\
184.1\end{array}$ & $\begin{array}{l}230.8 \\
186.0\end{array}$ & $\begin{array}{l}222.4 \\
186.8\end{array}$ & $\begin{array}{l}222.0 \\
186.1\end{array}$ & $\begin{array}{l}373.1 \\
202.7\end{array}$ & $\begin{array}{l}243.3 \\
183.2\end{array}$ \\
\hline World Bank Group & 88.4 & 95.8 & 101.3 & 108.5 & 115.5 & 123.0 & 128.9 & 137.6 & 146.4 & 150.5 & 153.9 & 158.2 & 160.8 & 163.5 & 163.4 & 165.1 & 166.0 & 167.9 & 168.3 & 167.7 & 119.6 & 163.5 \\
\hline IMF & 46.2 & 55.8 & 43.4 & 62.5 & 67.8 & 57.6 & 47.5 & 47.3 & 23.7 & 11.9 & 0.0 & 0.0 & 0.0 & 0.0 & 0.0 & 0.0 & 0.0 & 0.0 & 0.0 & 0.0 & 46.4 & 0.0 \\
\hline African Develop & 29.7 & 29.4 & 28.0 & 24.7 & 24.3 & 14.0 & 12.1 & 12.7 & 13.4 & 14.7 & 13.9 & 12.7 & 12.6 & 12.7 & 13.0 & 13.6 & 12.2 & 12.6 & 13.1 & 13.1 & 20.3 & 12.9 \\
\hline Others & 21.3 & 20.9 & 21.4 & 20.1 & 19.6 & 13.6 & 13.2 & 12.8 & 12.2 & 9.0 & 8.5 & 8.1 & 7.9 & 7.4 & 6.9 & 6.3 & 6.0 & 5.5 & 5.4 & 5.3 & 16.4 & 6.7 \\
\hline Official bilateral & 278.8 & 273.6 & 239.8 & 193.7 & 152.5 & 133.2 & 119.4 & 108.9 & 106.6 & 97.5 & 88.2 & 79.9 & 75.1 & 69.1 & 66.5 & 58.8 & 49.3 & 44.8 & 35.5 & 33.9 & 170.4 & 60.1 \\
\hline Paris Club & 188.3 & 181.6 & 158.8 & 138.8 & 116.8 & 105.1 & 93.9 & 86.2 & 85.2 & 83.4 & 80.4 & 77.4 & 73.7 & 68.0 & 65.6 & 58.0 & 48.4 & 43.9 & 34.7 & 33.0 & 123.8 & 58.3 \\
\hline Of which: ODA & 87.3 & 91.7 & 90.2 & 92.2 & 87.3 & 86.0 & 82.6 & 81.3 & 81.2 & 79.7 & 76.9 & 74.0 & 72.4 & 66.7 & 64.4 & 56.8 & 47.3 & 42.9 & 33.7 & 32.5 & 86.0 & 56.8 \\
\hline Other official bilateral and commercial & 90.5 & 91.9 & 81.1 & 55.0 & 35.7 & 28.0 & 25.5 & 22.6 & 21.4 & 14.0 & 7.8 & 2.5 & 1.4 & 1.1 & 0.9 & 0.9 & 0.9 & 0.9 & 0.9 & 0.9 & 46.6 & 1.8 \\
\hline Of which: ODA & 9.0 & 12.3 & 11.2 & 9.9 & 9.1 & 8.6 & 8.4 & 7.8 & 7.6 & 6.5 & 6.2 & 1.6 & 1.4 & 1.1 & 0.9 & 0.9 & 0.9 & 0.9 & 0.9 & 0.9 & 9.0 & 1.5 \\
\hline \multicolumn{23}{|c|}{ II. After enhanced HIPC assistance (incl. new } \\
\hline debt)2/ & 164.6 & 140.9 & 139.2 & 151.8 & 177.0 & 183.7 & 193.7 & 223.8 & 228.6 & 231.3 & 233.4 & 245.7 & 260.1 & 274.2 & 302.5 & 333.2 & 365.5 & 403.7 & 507.1 & 563.7 & 183.5 & 348.9 \\
\hline Existing debt & 159.0 & 129.4 & 121.8 & 128.2 & 146.8 & 146.1 & 140.5 & 146.8 & 127.6 & 121.3 & 113.9 & 109.0 & 111.9 & 114.2 & 114.7 & 115.9 & 116.5 & 120.5 & 186.8 & 206.0 & 136.8 & 131.0 \\
\hline Multilateral & 72.9 & 80.1 & 81.2 & 93.2 & 112.5 & 117.4 & 115.2 & 120.1 & 101.5 & 95.7 & 88.3 & 90.8 & 93.5 & 95.7 & 96.2 & 97.7 & 97.0 & 99.4 & 165.9 & 186.6 & 99.0 & 111.1 \\
\hline World Bank Group & 39.6 & 42.7 & 44.3 & 48.2 & 51.3 & 54.8 & 57.6 & 62.5 & 67.0 & 69.2 & 71.2 & 73.2 & 74.8 & 76.9 & 77.1 & 78.1 & 78.9 & 80.9 & 147.0 & 167.7 & 53.7 & 92.6 \\
\hline IMF & 14.7 & 26.3 & 26.3 & 35.1 & 46.9 & 55.9 & 47.5 & 47.3 & 23.7 & 11.9 & 0.0 & 0.0 & 0.0 & 0.0 & 0.0 & 0.0 & 0.0 & 0.0 & 0.0 & 0.0 & 33.6 & 0.0 \\
\hline African D & 9.5 & 10.3 & 9.8 & 9.1 & 9.0 & 3.2 & 5.6 & 5.9 & 6.4 & 13.2 & 13.9 & 12.7 & 12.6 & 12.7 & 13.0 & 13.6 & 12.2 & 12.6 & 13.1 & 13.1 & 8.2 & 12.9 \\
\hline Others & 9.1 & 0.8 & 0.8 & 0.8 & 5.2 & 3.5 & 4.4 & 4.4 & 4.4 & 1.4 & 3.2 & 4.9 & 6.1 & 6.2 & 6.1 & 6.0 & 6.0 & 5.9 & 5.8 & 5.8 & 3.5 & 5.6 \\
\hline Official bilateral & 86.1 & 49.3 & 40.6 & 35.0 & 34.3 & 28.7 & 25.4 & 26.6 & 26.1 & 25.6 & 25.6 & 18.2 & 18.4 & 18.5 & 18.5 & 18.2 & 19.5 & 21.0 & 20.9 & 19.5 & 37.8 & 19.8 \\
\hline Paris Club & 44.4 & 46.4 & 37.6 & 32.0 & 31.3 & 25.7 & 22.3 & 23.4 & 22.6 & 21.9 & 21.3 & 13.7 & 13.5 & 13.4 & 13.1 & 12.4 & 13.2 & 14.3 & 13.7 & 11.8 & 30.8 & 14.0 \\
\hline Of which: $\mathrm{ODA}$ & 5.2 & 6.4 & 6.7 & 7.4 & 9.7 & 9.8 & 11.4 & 12.9 & 12.6 & 12.3 & 12.2 & 12.1 & 12.0 & 11.9 & 11.6 & 10.9 & 11.7 & 12.9 & 13.0 & 11.8 & 9.5 & 12.0 \\
\hline Other official bilateral and commercial & 41.7 & 3.0 & 3.0 & 3.0 & 3.0 & 3.0 & 3.1 & 3.3 & 3.5 & 3.7 & 4.3 & 4.6 & 4.8 & 5.1 & 5.5 & 5.8 & 6.3 & 6.7 & 7.2 & 7.7 & 7.0 & 5.8 \\
\hline Of which: ODA & 5.5 & 0.3 & 0.3 & 0.3 & 0.3 & 0.3 & 0.3 & 0.3 & 0.3 & 0.3 & 0.7 & 0.7 & 0.7 & 0.7 & 0.7 & 0.7 & 0.7 & 0.7 & 0.7 & 0.7 & 0.8 & 0.7 \\
\hline \multicolumn{23}{|l|}{ III. After bilateral debt relief beyond HIPC } \\
\hline (incl. new debt) $2 / 3 /$ & 161.6 & 135.1 & 133.2 & 145.4 & 169.8 & 176.4 & 185.1 & 213.9 & 218.9 & 221.8 & 224.0 & 236.4 & 250.9 & 265.0 & 293.4 & 324.6 & 355.8 & 392.9 & 496.1 & 552.6 & 176.1 & 339.2 \\
\hline Existing debt & 156.0 & 123.7 & 115.7 & 121.8 & 139.5 & 138.9 & 131.9 & 136.8 & 117.9 & 111.8 & 104.5 & 99.7 & 102.7 & 105.1 & 105.6 & 107.3 & 106.8 & 109.6 & 175.9 & 195.0 & 129.4 & 121.2 \\
\hline Multilateral & 72.9 & 80.1 & 81.2 & 93.2 & 112.5 & 117.4 & 115.2 & 120.1 & 101.5 & 95.7 & 88.3 & 90.8 & 93.5 & 95.7 & 96.2 & 97.7 & 97.0 & 99.4 & 165.9 & 186.6 & 99.0 & 111.1 \\
\hline Official bilateral & 83.1 & 43.6 & 34.5 & 28.6 & 27.1 & 21.4 & 16.8 & 16.7 & 16.4 & 16.1 & 16.2 & 8.9 & 9.1 & 9.4 & 9.5 & 9.6 & 9.8 & 10.2 & 9.9 & 8.4 & 30.4 & 10.1 \\
\hline Paris Club & 41.4 & 40.6 & 31.6 & 25.6 & 24.1 & 18.4 & 13.7 & 13.4 & 12.9 & 12.4 & 11.9 & 4.4 & 4.3 & 4.2 & 4.0 & 3.7 & 3.5 & 3.5 & 2.7 & 0.7 & 23.4 & 4.3 \\
\hline Of which: $\mathrm{C}$ & 2.2 & 0.7 & 0.7 & 1.0 & 2.5 & 2.5 & 2.7 & 2.9 & 2.9 & 2.9 & 2.8 & 2.8 & 2.7 & 2.7 & 2.5 & 2.2 & 2.0 & 2.0 & 2.0 & 0.7 & 2.1 & 2.3 \\
\hline Other official bilater & 41.7 & 3.0 & 3.0 & 3.0 & 3.0 & 3.0 & 3.1 & 3.3 & 3.5 & 3.7 & 4.3 & 4.6 & 4.8 & 5.1 & 5.5 & 5.8 & 6.3 & 6.7 & 7.2 & 7.7 & 7.0 & 5.8 \\
\hline Of which: ODA & 5.5 & 0.3 & 0.3 & 0.3 & 0.3 & 0.3 & 0.3 & 0.3 & 0.3 & 0.3 & 0.7 & 0.7 & 0.7 & 0.7 & 0.7 & 0.7 & 0.7 & 0.7 & 0.7 & 0.7 & 0.8 & 0.7 \\
\hline \multicolumn{23}{|l|}{ Memorandum items: } \\
\hline Debt service of new debt & 5.6 & 11.4 & 17.5 & 23.6 & 30.2 & 37.6 & 53.1 & 77.1 & 101.0 & 109.9 & 119.5 & 136.7 & 148.2 & 159.9 & 187.8 & 217.3 & 249.0 & 283.3 & 320.2 & 357.7 & 46.7 & 218.0 \\
\hline Multilateral & 1.8 & 3.4 & 5.1 & 6.9 & 8.9 & 11.0 & 21.1 & 39.2 & 57.2 & 59.8 & 62.7 & 62.0 & 54.3 & 46.7 & 55.0 & 63.9 & 73.4 & 83.9 & 95.2 & 106.9 & 21.4 & 70.4 \\
\hline World Bank Group & 1.6 & 3.4 & 5.1 & 6.9 & 8.9 & 11.0 & 13.3 & 15.8 & 18.2 & 20.8 & 23.7 & 30.8 & 38.7 & 46.7 & 55.0 & 63.9 & 73.4 & 83.9 & 95.2 & 106.9 & 10.5 & 61.8 \\
\hline IM & 0.2 & 0.0 & 0.0 & 0.0 & 0.0 & 0.0 & 7.8 & 23.4 & 39.0 & 39.0 & 39.0 & 31.2 & 15.6 & 0.0 & 0.0 & 0.0 & 0.0 & 0.0 & 0.0 & 0.0 & 10.9 & 8.6 \\
\hline Others & 0.0 & 0.0 & 0.0 & 0.0 & 0.0 & 0.0 & 0.0 & 0.0 & 0.0 & 0.0 & 0.0 & 0.0 & 0.0 & 0.0 & 0.0 & 0.0 & 0.0 & 0.0 & 0.0 & 0.0 & 0.0 & 0.0 \\
\hline Official bilateral & 3.8 & 8.1 & 12.3 & 16.7 & 21.4 & 26.5 & 32.0 & 37.9 & 43.8 & 50.1 & 56.9 & 74.7 & 93.9 & 113.2 & 132.8 & 153.4 & 175.6 & 199.4 & 225.0 & 250.8 & 25.3 & 147.6 \\
\hline \multicolumn{23}{|l|}{ Nominal HIPC relief } \\
\hline Under the enhanced HIPC initiative & 305.3 & 346.0 & 312.1 & 281.2 & 232.8 & 195.2 & 180.6 & 172.5 & 174.8 & 162.3 & 150.6 & 149.9 & 144.5 & 138.4 & 135.1 & 127.9 & 117.0 & 110.4 & 35.5 & 14.0 & 236.3 & 112.3 \\
\hline Multilatera & 112.6 & 121.8 & 112.9 & 122.5 & 114.7 & 90.8 & 86.6 & 90.3 & 94.3 & 90.4 & 88.0 & 88.2 & 87.8 & 87.9 & 87.1 & 87.3 & 87.2 & 86.6 & 20.9 & & 103.7 & 80.1 \\
\hline Official bilateral & 192.7 & 224.2 & 199.3 & 158.7 & 118.1 & 104.5 & 94.0 & 82.2 & 80.5 & 71.9 & 62.5 & 61.7 & 56.8 & 50.5 & 48.0 & 40.6 & 29.8 & 23.8 & 14.6 & 14.4 & 132.6 & 40.3 \\
\hline
\end{tabular}


Table 9. Ghana: Net Present Value of External Debt, 2003-2023

(In millions of U.S. dollars; unless otherwise indicated)

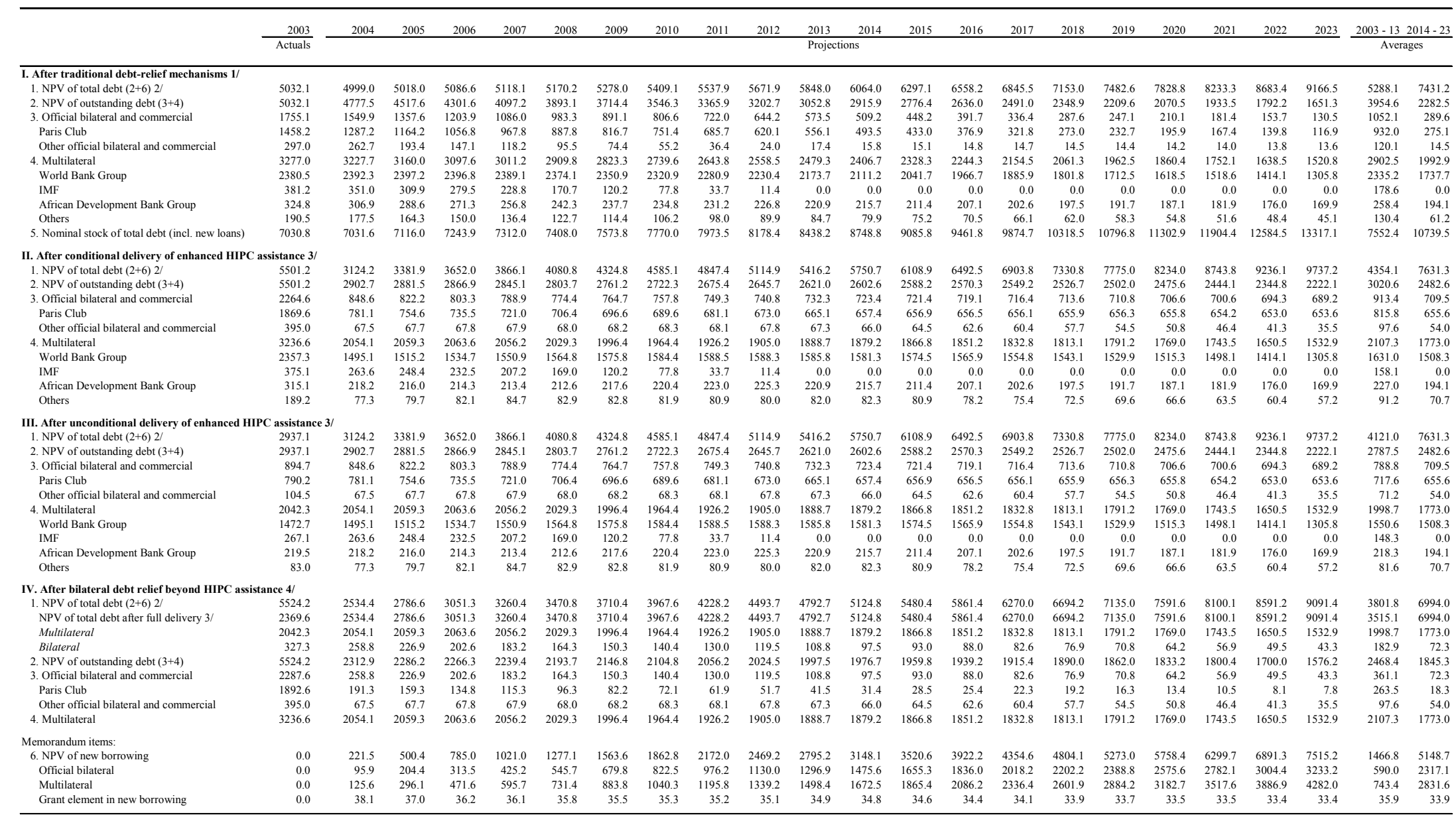

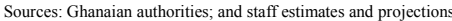

1/Refers to public and publicly guaranteed external debt only and assumes a stock-of-debt operation on Naples terms (67 percent NPV reduction) at end-2000 with a January 1983 cut-off date, and at least comparable action by other official bilateral creditors The counted on the basis of the average commercial interest reference rate for the respective currency, derived over the six-month period prior to the latest date for which actual data are available (December 2003).

3/ Using a June 1999 cutofff date, with completion point in July, 2004. For conditional delivery. NPV of total debt assuming HIPC

For unconditional delivery, NPV of total debt assuming entire HIIPC Initiative assistance is fully delivered as of end-December 2003 .
$4 /$ After debt relief beyond HIPC offered by some of the Paris Club creditors on a voluntary basis; calculated using a June 1999 cutoff date. 
Table 10. Ghana: External Debt Indicators, 2003-2023 1/

In percent, unless otherwise indicate

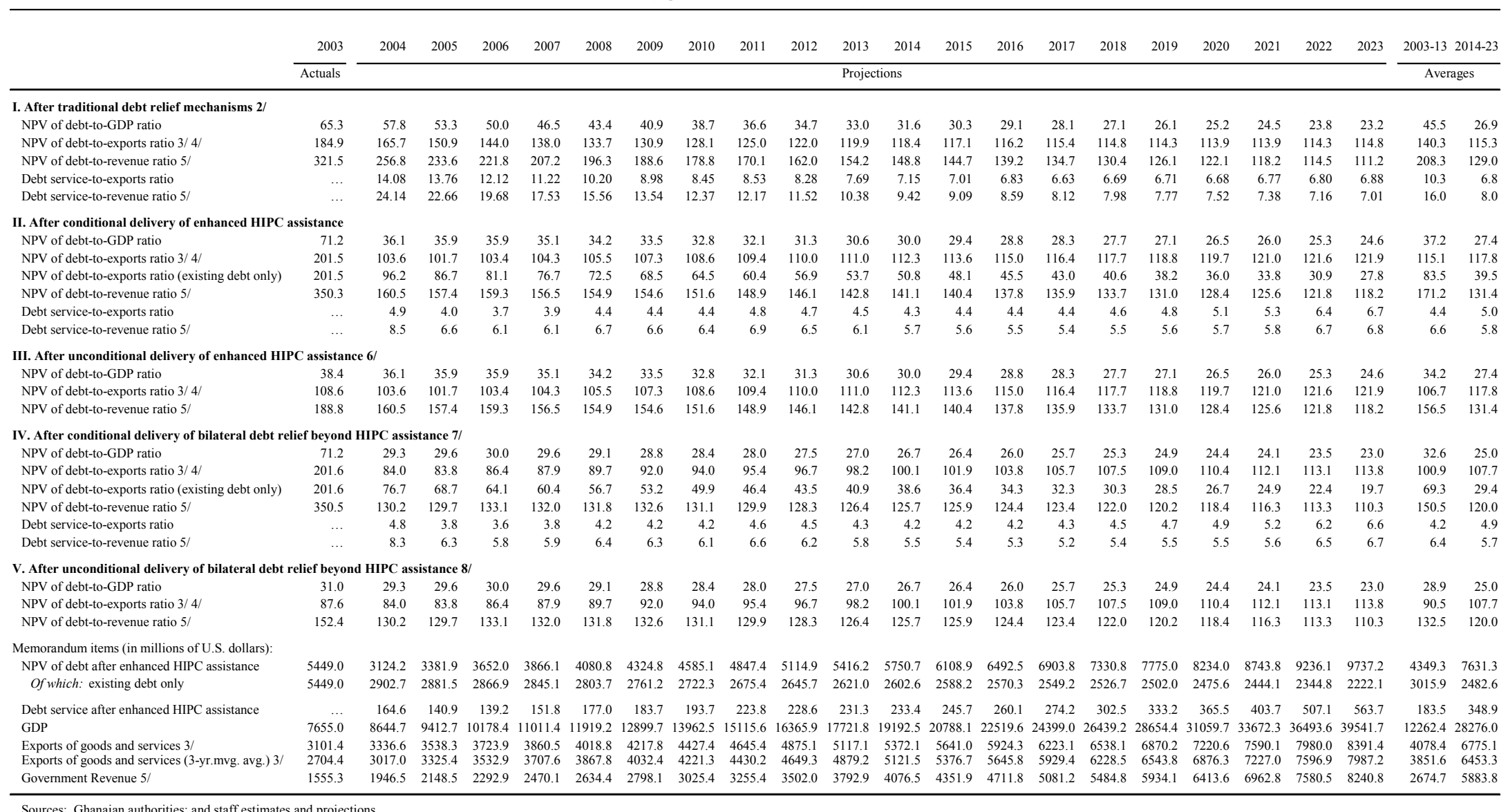

Sources: Ghanaian authorities; and staff estimates and projections.

1/ All debt indicators refer to public and publicly guaranteed (PPG) debt and are defined after rescheduling, unless otherwise indicated.

/ Reflect a hypothetical stock-of-debt operation on Naples terms at end-2000 for Paris Club creditors as calculated in the HIPC decision point Document.

A IMF, Balance of Payments Manual, 5th edition, 1993.

a three-year average of exports on the previous year (e.g., export average over 2001-2003 for NPV of debt-to-exports ratio in 2003).

6/ Assuming unconditional/full delivery of HIPC assistance in end-2003.

7/ Assuming full delivery of HIPC assistance in July 2004 .

8/ Some Paris Club creditors have agreed to extend additional debt relief beyond HIPC assistance. 


\begin{tabular}{|c|c|c|c|c|c|c|c|c|c|c|c|c|c|c|c|c|c|c|c|c|c|c|}
\hline \multirow[b]{3}{*}{ Baseline scenario } & 2004 & 2005 & 2006 & 2007 & 2008 & 2009 & 2010 & 2011 & 2012 & 2013 & 2014 & 2015 & 2016 & 2017 & 2018 & 2019 & 2020 & 2021 & 2022 & 2023 & 2004-13 & $2014-23$ \\
\hline & \multirow{2}{*}{\multicolumn{20}{|c|}{ Projections }} & \multirow{2}{*}{\multicolumn{2}{|c|}{ Averages }} \\
\hline & & & & & & & & & & & & & & & & & & & & & & \\
\hline Debt service-to-exports ratio $2 /$ & 4.9 & 4.0 & 3.7 & 3.9 & 4.4 & 4.4 & 4.4 & 4.8 & 4.7 & 4.5 & 4.3 & 4.4 & 4.4 & 4.4 & 4.6 & 4.8 & 5.1 & 5.3 & 6.4 & 6.7 & 4.4 & 5.0 \\
\hline Debt se & 8.5 & 6.6 & 6.1 & 6.1 & 6.7 & 6.6 & 6.4 & 6.9 & 6.5 & 6.1 & 5.7 & 5.6 & 5.5 & 5.4 & 5.5 & 5.6 & 5.7 & 5.8 & 6.7 & 6.8 & 6.6 & 5.8 \\
\hline o-revenue ratio $3 /$ & 160.5 & 157.4 & 159.3 & 156.5 & 154.9 & 154.6 & 151.6 & 148.9 & 146.1 & 142.8 & 141.1 & 140.4 & 137.8 & 135.9 & 133.7 & 131.0 & 128.4 & 125.6 & 121.8 & 118.2 & 153.2 & 131.4 \\
\hline \multicolumn{23}{|l|}{ Memorandum items (in $\mathrm{n}$} \\
\hline & $3,124.2$ & $3,381.9$ & $3,652.0$ & $3,866.1$ & $4,080.8$ & $4,324.8$ & $4,585.1$ & $4,847.4$ & $5,114.9$ & $5,416.2$ & $5,750.76$ & $6,108.9$ & $6,492.5$ & $6,903.8$ & $7,330.8$ & $7,775.0$ & 234.0 & $8,743.8$ & $9,236.1$ & 737.2 & 4239.3 & 31.3 \\
\hline ofw & 221.5 & 500.4 & 785.0 & $1,021.0$ & $1,277.1$ & $1,563.6$ & $1,862.8$ & $2,172.0$ & $2,469.2$ & 2,795.2 & $3,148.1 \quad 3$ & $3,520.6$ & $3,922.2$ & $4,354.6$ & 4,804.1 & $5,273.0$ & 758.4 & $6,299.7$ & $6,891.3$ & 515.2 & 1466.8 & 5148.7 \\
\hline Debt s & 164.6 & 140.9 & 139.2 & 151.8 & 177.0 & 183.7 & 193.7 & 223.8 & 228.6 & 231.3 & 233.4 & 245.7 & 260.1 & .2 & 2.5 & 3.2 & 5.5 & 13.7 & 7.1 & 63.7 & 33.5 & 8.9 \\
\hline & 5.6 & 12.0 & 18.4 & 24.6 & 31.2 & 38.6 & 54.1 & 78.0 & 1.7 & 0.5 & 119.8 & 136.8 & 8.2 & 9 & 7.8 & 3 & 9.0 & 3.3 & .2 & 7.7 & 7.5 & 18.0 \\
\hline $\operatorname{Expo}$ & $3,017.0$ & $3,325.4$ & $3,532.9$ & $3,707.6$ & $3,867.8$ & $4,032.4$ & $4,221.3$ & $4,430.2$ & $4,649.3$ & $4,879.2$ & $5,121.55$ & $5,376.7$ & $5,645.8$ & $5,929.4$ & $6,228.5$ & $6,543.8$ & $6,876.3$ & $7,227.0$ & 7,596.9 & 7,987.2 & 3966.3 & 6453.3 \\
\hline Еxpo & $3,336.6$ & $3,538.3$ & $3,723.9$ & $3,860.5$ & $4,018.8$ & $4,217.8$ & $4,427.4$ & $4,645.4$ & $4,875.1$ & $5,117.1$ & $5,372.15$ & $5,641.0$ & $5,924.3$ & $6,223.1$ & $6,538.1$ & $6,870.2$ & 220.6 & 990.1 & 80.0 & 391.4 & 4176.1 & 6775.1 \\
\hline Revenues & 1946.5 & 2148.5 & 2292.9 & 2470.1 & 2634.4 & 2798.1 & 3025.4 & 3255.4 & 3502.0 & 3792.9 & 4076.5 & 4351.9 & 4711.8 & 5081.2 & 5484.8 & 5934.1 & 6413.6 & 6962.8 & 7580.5 & 8240.8 & 2786.6 & 5883.8 \\
\hline \multicolumn{23}{|l|}{ Sensivity analysis } \\
\hline \multicolumn{23}{|l|}{ Alternative scenario (price shock) 4} \\
\hline Debt service-to-exports ratio $2 /$ & 4.9 & 4.3 & 4.2 & 4.4 & 5.0 & 5.0 & 5.1 & 5.6 & 5.6 & 5.4 & 5.3 & 5.3 & 5.6 & 5.8 & 6.1 & 6.5 & 6.9 & 7.3 & 8.5 & 9.0 & 5.0 & 6.6 \\
\hline Debt ser & 8.5 & 6.8 & 6.5 & 6.6 & 7.3 & 7.3 & 7.2 & 7.7 & 7.4 & 7.0 & 6.7 & 6.7 & 6.7 & 6.8 & 7.0 & 7.3 & 7.5 & 7.7 & 8.6 & 8.8 & 7.2 & 7.4 \\
\hline NPV of debt-to-revenue ratio $3 /$ & 160.5 & 165.5 & 171.7 & 173.1 & 175.3 & 178.5 & 178.4 & 178.4 & 177.9 & 176.6 & 176.8 & 178.2 & 176.8 & 176.0 & 174.6 & 172.4 & 170.1 & 167.3 & 163.3 & 159.2 & 173.6 & 171.5 \\
\hline \multicolumn{23}{|l|}{ Memo } \\
\hline & $3,124.2$ & $3,484.0$ & $3,859.4$ & $4,190.1$ & $4,531.2$ & $4,904.2$ & $5,301.2$ & $5,708.5$ & $6,129.5$ & $6,593.2$ & $7,099.77$ & $7,640.5$ & $8,213.5$ & $8,821.0$ & $9,451.4$ & $10,105.9$ & $10,782.8$ & $11,518.6$ & $12,245.0$ & $12,988.9$ & 782.6 & 9886.7 \\
\hline & & & & $1,345.0$ & $1,727.5$ & $2,143.0$ & & & & & & & & & & & & & & & 10.0 & 04.2 \\
\hline & 16 & 143.7 & 145.0 & & & 199.4 & & & & & & & & & & & & & & & 3.0 & 7.9 \\
\hline & & & & & & & & & & & & & & & & & & & & & 2.0 & 7.0 \\
\hline & & $3,248.8$ & $3,378.8$ & $3,473.7$ & $3,628.4$ & $3,785.9$ & $3,967.4$ & $4,168.7$ & $4,379.9$ & $4,601.7$ & $4,835.75$ & $5,082.4$ & & & & & & & & & 5.0 & 5.7 \\
\hline Ex & & $3,308.3$ & $3,491.6$ & $3,621.3$ & $3,772.3$ & $3,964.0$ & $4,166.0$ & $4,376.1$ & $4,597.7$ & $4,831.4$ & $5,077.955$ & $5,337.9$ & $5,612.1$ & & 66.9 & & 9.2 & 28.2 & 3 & 7.4 & 5.5 & 7.7 \\
\hline Revenues & 1946.5 & 2104.8 & 2247.3 & 2421.2 & 2584.8 & 2746.7 & 2972.1 & 3200.3 & 3444.9 & 3733.8 & 4015.2 & 4288.4 & 4646.2 & 5013.3 & 5414.6 & 5861.6 & 6338.6 & 6885.1 & 7500.3 & 8157.9 & 2740.2 & 5812.1 \\
\hline \\
\hline & 5.0 & 4.1 & 4.0 & 4.2 & 4.8 & 8 & 4.8 & 5.4 & 5.3 & 5.3 & $2^{2}$ & 4 & 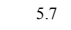 & & 6.4 & 9 & & 7. & & & 4.8 & 7.0 \\
\hline $\mathrm{D}$ & & 6.8 & 6.4 & 6.6 & 7.3 & 7.2 & 7.1 & & & & 6.8 & .0 & 7.2 & & & 7.9 & & 8.5 & & & 7.2 & 8.0 \\
\hline $\mathrm{NPV}$ of debt-to-revenue ratio & 165.2 & 166.2 & 172.0 & 172.7 & 174.7 & 177.4 & 176.9 & 178.7 & 180.0 & 180.3 & 182.7 & 186.8 & 188.5 & 191.2 & 193.6 & 195.5 & 197.5 & 199.0 & 199.2 & 199.4 & 174.4 & 193.3 \\
\hline \\
\hline & $3,215.0$ & $3,571.9$ & $3,943.6$ & $4,266.8$ & $4,601.0$ & $4,964.1$ & $5,352.2$ & $5,817.2$ & $6,302.2$ & $6,837.1$ & $7,448.988$ & $8,128.4$ & $8,881.2$ & 9 & $10,619.1$ & $11,602.5$ & & 13,8 & & 9 & 387.1 & 11445.4 \\
\hline c & & 690.3 & $1,076.7$ & & $1,797.3$ & $2,202.9$ & $2,630.0$ & $3,141.7$ & $3,656.5$ & $4,216.1$ & $4,846.3$ & $5,540.2$ & $6,310.9$ & 7,16 & $8,092.3$ & & & & & & & 8962.8 \\
\hline & 167.1 & 146.1 & 147.3 & 162.8 & 191.1 & 200.9 & 214.2 & & 260.0 & 268.7 & 277.9 & & & & & & & & & & & 49 \\
\hline & 8.1 & 17.3 & 26.5 & 35.5 & 3 & & 74.6 & & & 9 & 1.3 & & & & & & & & & & & \\
\hline & 3,4 & $\begin{array}{l}3,325.4 \\
3,3583\end{array}$ & $\begin{array}{r}3,532.9 \\
37220\end{array}$ & $3,707.6$ & 3,86 & 4,03 & $4,221.3$ & 4,4 & 4,6 & 4,8 & 5,1 & & & & & & & & & & & \\
\hline & & & & & & & & & & & & $\begin{array}{l}5,641.0 \\
43519\end{array}$ & $\begin{array}{l}5,924.3 \\
47118\end{array}$ & & & & & & & & & \\
\hline Revenues & $1,946.5$ & $2,148.5$ & $2,292.9$ & $2,470.1$ & $2,634.4$ & $2,798.1$ & $3,025.4$ & $3,255.4$ & $3,502.0$ & $3,792.9$ & $4,076.5$ & $4,351.9$ & $4,711.8$ & $5,081.2$ & $5,484.8$ & $5,934.1$ & $6,413.6$ & $6,962.8$ & 7,580.5 & 3,240.8 & 2786.6 & 6883.8 \\
\hline \\
\hline & 4.9 & 4.1 & 4.0 & 4.2 & 4. & & & & & & 2 & & & & & & & & & & . & 6.8 \\
\hline & 85 & 66 & 6. & 64 & 71 & & & & & & & 5 & & & & & & & & & & 3 \\
\hline $\mathrm{NPV}$ of debt- & 160.5 & 160.0 & 164.9 & 164.5 & 165.2 & 167.2 & 166.3 & 166.0 & 165.6 & 164.7 & 165.7 & 168.4 & 169.0 & 170.7 & 172.4 & 173.8 & 175.5 & 77.0 & 177.8 & 178.9 & 64.5 & 172.9 \\
\hline \multicolumn{23}{|l|}{ Memor } \\
\hline & 3,12 & $3,416.4$ & , & $3,997.1$ & $4,255.2$ & 4,54 & $4,862.2$ & $5,190.1$ & 5,5 & $5,924.4$ & $6,362.5$ & $6,852.7$ & 7,3 & 8,0 & 8 & & 10, & & 12, & & 7 & \\
\hline & & & 870.1 & $\begin{array}{l}1,151.9 \\
1555\end{array}$ & & $1,784.7$ & $2,140.0$ & 2,514.6 & 2,88 & 3,30 & & & & & & & 7,6 & 3 & & & & \\
\hline & . & & & 15 & & 189.7 & 201.2 & 233.0 & 23 & & & & & & & & & & & & 4 & 8 \\
\hline & 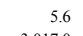 & & & & & & & & & & & & & & & & & & & & 3 & 9 \\
\hline Ex & & & & & & & & & & & & & & & & & & & & & 9.4 & \\
\hline Services, annual & & $\begin{array}{l}3,458.1 \\
2,358\end{array}$ & $\begin{array}{l}3,578.2 \\
2,2659\end{array}$ & $\begin{array}{l}3,711.3 \\
24293\end{array}$ & $\begin{array}{l}3,854.0 \\
256764\end{array}$ & $\begin{array}{l}4,002.4 \\
27194\end{array}$ & $\begin{array}{l}4,156.7 \\
29230\end{array}$ & $\begin{array}{l}4,317.0 \\
3,259\end{array}$ & $\begin{array}{l}4,483.5 \\
3.315\end{array}$ & $\begin{array}{l}4,656.7 \\
35971\end{array}$ & $\begin{array}{l}4,836.6 \\
3.8404\end{array}$ & $\begin{array}{l}5,023.7 \\
40702\end{array}$ & $\begin{array}{l}5,218.1 \\
4378,5\end{array}$ & $\begin{array}{l}5,420.1 \\
46893\end{array}$ & $\begin{array}{l}5,630.2 \\
5,268\end{array}$ & $\begin{array}{ll}48.5 \\
014\end{array}$ & $\begin{array}{l}775.4 \\
96.5\end{array}$ & $\begin{array}{ll}311.2 \\
50.5\end{array}$ & 56.4 & $\begin{array}{r}6,811.2 \\
72803\end{array}$ & $\begin{array}{l}3955.5 \\
27061\end{array}$ & $\begin{array}{l}5773.1 \\
5348.5\end{array}$ \\
\hline Revenues & 1,946.5 & $2,135.8$ & & & & & & & & & & & & & & & & & & & 2706.1 & \\
\hline
\end{tabular}

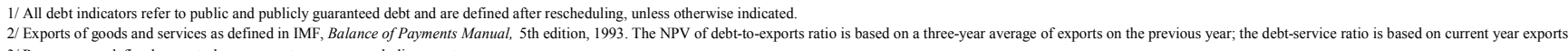

3/

$5 /$ Decrease in the grant

6/ GDP growth is one percent lower than baseline. 
Table 12. Ghana: Delivery of IDA Assistance Under the HIPC Initiative, 2001-2022

(In millions of U.S. dollars, unless otherwise indicated)

\begin{tabular}{|c|c|c|c|c|c|c|c|c|c|c|c|}
\hline & 2001 & 2002 & 2003 & 2004 & 2005 & 2006 & 2007 & 2008 & 2009 & 2010 & 2011 \\
\hline IDA debt service before HIPC relief & 55.1 & 62.2 & 66.7 & 72.4 & 78.6 & 84.6 & 89.4 & 95.1 & 101.2 & 105.7 & 111.5 \\
\hline Principal & 31.8 & 39.1 & 43.8 & 50.0 & 56.5 & 62.9 & 68.3 & 74.5 & 81.1 & 86.3 & 92.7 \\
\hline Interest & 23.4 & 23.1 & 22.8 & 22.5 & 22.1 & 21.7 & 21.2 & 20.6 & 20.1 & 19.5 & 18.8 \\
\hline IDA debt service after HIPC relief & 55.1 & 29.2 & 21.707 & 23.6 & 25.6 & 27.5 & 29.1 & 31.0 & 32.9 & 34.4 & 36.3 \\
\hline Principal & 31.8 & 17.9 & 14.3 & 16.3 & 18.4 & 20.5 & 22.2 & 24.2 & 26.4 & 28.1 & 30.2 \\
\hline Interest & 23.4 & 11.3 & 7.4 & 7.3 & 7.2 & 7.1 & 6.9 & 6.7 & 6.5 & 6.3 & 6.1 \\
\hline IDA assistance 1/ & 0.0 & 32.9 & 45.0 & 48.9 & 53.0 & 57.0 & 60.3 & 64.1 & 68.2 & 71.3 & 75.2 \\
\hline Principal & 0.0 & 21.1 & 29.6 & 33.7 & 38.1 & 42.4 & 46.0 & 50.2 & 54.7 & 58.2 & 62.5 \\
\hline Interest & 0.0 & 11.8 & 15.4 & 15.2 & 14.9 & 14.6 & 14.3 & 13.9 & 13.5 & 13.1 & 12.7 \\
\hline \multicolumn{12}{|l|}{ Memorandum item: } \\
\hline $\begin{array}{l}\text { IDA debt relief as percent of IDA } \\
\text { debt service due (in percent) }\end{array}$ & 0.00 & 0.53 & 0.67 & 0.67 & 0.67 & 0.67 & 0.67 & 0.67 & 0.67 & 0.67 & 0.67 \\
\hline Interim assistance 2/ & 94.70 & & & & & & & & & & \\
\hline \multirow[t]{2}{*}{ Interim relief as percent of total } & 12.1 & & & & & & & & & & \\
\hline & 2012 & 2013 & 2014 & 2015 & 2016 & 2017 & 2018 & 2019 & 2020 & 2021 & 2022 \\
\hline IDA debt service before HIPC relief & 117.7 & 120.5 & 122.7 & 126.1 & 127.5 & 128.5 & 128.0 & 128.9 & 129.2 & 129.0 & 128.0 \\
\hline Principal & 99.6 & 103.2 & 106.1 & 110.4 & 112.6 & 114.4 & 114.8 & 116.6 & 117.7 & 118.4 & 118.3 \\
\hline Interest & 18.1 & 17.3 & 16.6 & 15.7 & 14.9 & 14.1 & 13.2 & 12.3 & 11.5 & 10.6 & 9.7 \\
\hline IDA debt service after HIPC relief & 38.3 & 39.2 & 39.9 & 41.1 & 41.5 & 41.8 & 41.7 & 42.0 & 42.1 & 42.0 & 106.6 \\
\hline Principal & 32.4 & 33.6 & 34.5 & 35.9 & 36.7 & 37.2 & 37.4 & 38.0 & 38.3 & 38.6 & 98.7 \\
\hline Interest & 5.9 & 5.6 & 5.4 & 5.1 & 4.9 & 4.6 & 4.3 & 4.0 & 3.7 & 3.4 & 8.0 \\
\hline IDA assistance 1/ & 79.4 & 81.3 & 82.7 & 85.0 & 86.0 & 86.6 & 86.3 & 87.0 & 87.1 & 87.0 & 21.4 \\
\hline Principal & 67.2 & 69.6 & 71.5 & 74.4 & 75.9 & 77.1 & 77.4 & 78.6 & 79.4 & 79.9 & 19.6 \\
\hline Interest & 12.2 & 11.7 & 11.2 & 10.6 & 10.1 & 9.5 & 8.9 & 8.3 & 7.7 & 7.1 & 1.7 \\
\hline \multicolumn{12}{|l|}{$\begin{array}{l}\text { Memorandum item: } \\
\text { IDA debt relief as percent of IDA }\end{array}$} \\
\hline $\begin{array}{l}\text { IDA debt relief as percent of IDA } \\
\text { debt service due (in percent) }\end{array}$ & 0.67 & 0.67 & 0.67 & 0.67 & 0.67 & 0.67 & 0.67 & 0.67 & 0.67 & 0.67 & 0.17 \\
\hline
\end{tabular}

Sources: Ghanaian authorities; and IDA staff estimates.

1/ Total debt service reduction of US\$1445.7 million in nominal terms corresponding to US\$781.5 million in NPV terms, using end-2000 discount rates and exchange rates.

2/ In net present value (NPV) terms; assuming a Decision Point in February 2002 and a Completion point in July 2004. 
Table 13. Ghana: Delivery of IMF Assistance under the Enhanced HIPC Initiative 1/ (In millions of SDRs, unless otherwise indicated)

\begin{tabular}{|c|c|c|c|c|c|c|c|c|}
\hline & \multicolumn{3}{|c|}{ Actual } & \multirow[b]{2}{*}{2005} & \multirow[b]{2}{*}{2006} & \multirow[b]{2}{*}{2007} & \multirow[b]{2}{*}{2008} & \multirow[b]{2}{*}{2009} \\
\hline & 2002 & 2003 & 2004 & & & & & \\
\hline Delivery schedule of IMF assistance (in percent of total assistance) $2 /$ & 8.2 & 14.9 & 20.0 & 16.6 & 6.6 & 18.6 & 14.4 & 0.9 \\
\hline Debt Service due on IMF obligations 3/ & 10.5 & 17.1 & 31.5 & 38.4 & 30.0 & 37.6 & 33.3 & 18.6 \\
\hline Principal & 8.2 & 15.1 & 29.6 & 36.3 & 28.0 & 35.8 & 31.7 & 17.2 \\
\hline Interest & 2.3 & 2.0 & 1.9 & 2.1 & 2.0 & 1.8 & 1.6 & 1.5 \\
\hline \multicolumn{9}{|l|}{ IMF assistance--deposits into Ghana's account } \\
\hline Interim assistance & 9.91 & 15.15 & & & & & & \\
\hline Completion point assistance & & & 64.987 & $4 /$ & & & & \\
\hline IMF assistance--drawdown schedule 5/ & 7.3 & 13.5 & 21.2 & 19.9 & 11.5 & 18.4 & 14.0 & 1.2 \\
\hline IMF assistance without interest & 7.3 & 13.4 & 18.1 & 14.9 & 5.9 & 16.7 & 12.9 & 0.8 \\
\hline Estimated interest earnings & $\ldots$ & 0.1 & 3.1 & 5.0 & 5.6 & 1.7 & 1.1 & 0.4 \\
\hline Debt service due on IMF obligations after IMF assistance 5/ & 3.2 & 3.6 & 10.3 & 18.5 & 18.5 & 19.2 & 19.3 & 17.5 \\
\hline \multicolumn{9}{|l|}{ Share of debt service due on IMF obligations covered by } \\
\hline IMF assistance (in percent) $5 /$ & 69.7 & 79.1 & 67.2 & 51.8 & 38.4 & 48.9 & 42.1 & 6.3 \\
\hline $\begin{array}{l}\text { Proportion (in percent) of each principal repayment obligation falling due during } \\
\text { to be paid by IMF assistance from the principal deposited in Ghana's account }\end{array}$ & 89.3 & 89.1 & 60.8 & 41.1 & 21.0 & 46.6 & 40.8 & 4.9 \\
\hline \multicolumn{9}{|l|}{$\begin{array}{l}\text { Memorandum items: } \\
\text { (Based on debt service data and exchange rates as of end-2000) }\end{array}$} \\
\hline Total debt service due (in millions of U.S. dollars) 6/ $7 /$ & 375 & 368 & 376 & 368 & 347 & 350 & 363 & 359 \\
\hline Debt service due on IMF obligations (in millions of U.S. dollars) 7/ & 15.4 & 20.6 & 39.5 & 48.0 & 37.0 & 33.3 & 27.8 & 8.7 \\
\hline Debt service due on current IMF obligations after IMF assistance 7/ & 8.0 & 7.1 & 18.3 & 28.1 & 25.5 & 14.9 & 13.7 & 7.5 \\
\hline (in percent of exports) & 0.3 & 0.3 & 0.8 & 1.1 & 0.9 & 0.5 & 0.4 & 0.2 \\
\hline Share of total debt service covered by IMF assistance (in percent) 7/ & 2.0 & 3.7 & 5.6 & 5.4 & 3.3 & 5.3 & 3.9 & 0.3 \\
\hline
\end{tabular}

Source: Fund staff estimates.

1/ Total IMF assistance under the enhanced HIPC Initiative is SDR 90.05 million calculated on the basis of data available at the decision point, excluding interest earned on Ghana's account and on committed but undisbursed amounts as described in footnote 6 .

2/ While the IMF deposited 11 percent of enhanced assistance into Ghana's account after the decision point, the delivery schedule for 2002 shows the share (8.2 percent) of enhanced assistance applied to Ghana's principal repayment obligations falling due from mid-February to end-December 2002.

3/ Forthcoming obligations estimated based on rates and principal schedules in effect as of end-December 2001. Interest obligations include net SDR charges and assessments.

4/ A final disbursement of SDR 64.987 million (plus accrued interest) assumed to be disbursed into Ghana's account at the completion point in June 2004, which is reflected in the calculation of interest.

5/ Includes estimated interest earnings on: (1) amounts held in Ghana's account; and (2), up to the completion point, amounts committed but not yet disbursed. It is assumed that these amounts earn a rate of return of 5 percent in SDR terms; actual interest earnings may be higher or lower. Interest accrued on (1) during a calendar year will be used toward the first repayment obligation(s) falling due in the following calendar year except in the final year, when it will be used toward payment of the final obligation(s) falling due in that year. Interest accrued on (2) during the interim period will be used toward the repayment of obligations falling due during the three years after the completion point.

6/ After traditional debt relief mechanisms.

7/ Excludes charges in the SDR Department of the IMF. 
Table 14. Ghana: Status of Creditor Participation Under the Enhanced HIPC Initiative

\begin{tabular}{|c|c|c|c|c|}
\hline & $\begin{array}{l}\text { Debt relief } \\
\text { in NPV terms } \\
\text { (US\$ millions) 1/ }\end{array}$ & $\begin{array}{l}\text { Percentage of } \\
\text { total assistance }\end{array}$ & $\begin{array}{c}\text { Satisfactory } \\
\text { reply }\end{array}$ & $\begin{array}{c}\text { Modalities to } \\
\text { deliver debt relief }\end{array}$ \\
\hline IDA/IBRD & 781.5 & 35.7 & Yes & $\begin{array}{l}\text { IDA relief is being provided over twenty years (2000-22). } \\
\text { Interim assistance has been provided equivalent to a } 67.4 \\
\text { percent reduction on Ghana's debt service to IDA, and totalled } \\
\text { US\$ } 98 \text { million as of end-May } 2003 \text {. After completion point, } \\
\text { assistance will resume in the same manner. }\end{array}$ \\
\hline IMF & 112.1 & 5.1 & Yes & $\begin{array}{l}\text { IMF assistance will be delivered through grants from the } \\
\text { PRGF/HIPC Trust Fund to the member's umbrella account. } \\
\text { These resources, plus accrued interest, will be used to reduce the } \\
\text { amortization falling due. Interim assistance of about SDR } 25.1 \\
\text { million has been delivered until Mav } 2004 \text {. }\end{array}$ \\
\hline AfDB/AFDF & 130.9 & 6.0 & Yes & $\begin{array}{l}\text { As of end-June, interim assistance of US } \$ 51.8 \text { million has been } \\
\text { provided. Total assistance will cover } 80 \text { percent of the debt } \\
\text { service falling due through } 2013 \text {. The total of debt relief is } \\
\text { expected to be delivered by January } 2013 \text {. }\end{array}$ \\
\hline EU & 14.3 & 0.7 & Yes & $\begin{array}{l}\text { Interim relief was provided in the form of } 100 \text { percent debt } \\
\text { service relief on eight outstanding EDF loans, and totalled EUR } \\
2.2 \mathrm{mn} \text { as of June } 2003 \text {. Modalities for the delivery of assistance } \\
\text { after completion point remain to be specified. }\end{array}$ \\
\hline EIB & 27.0 & 1.2 & Yes & $\begin{array}{l}\text { As of June } 2003 \text {, interim relief amounting to EUR } 2.5 \mathrm{mn} \text { has } \\
\text { been delivered. Assistance will most likely be provided in the } \\
\text { form of a } 100 \text { percent reduction of the debt service on loans to } \\
\text { the Volta River Authority. Modalities for this are still to be } \\
\text { finalized and would require consent of the Government of } \\
\text { Ghana. }\end{array}$ \\
\hline IFAD & 17.7 & 0.8 & Yes & $\begin{array}{l}\text { Assistance will be delivered at the Completion Point, through a } \\
\text { reduction of debt service payments on eligible debt by up to } 100 \\
\text { percent until the target of US } \$ 17.7 \mathrm{mn} \text { in NPV terms is reached. } \\
\text { Precise modalities for delivery of assistance remain to be } \\
\text { specified. Preliminary estimates show that IFAD's relief could } \\
\text { be delivered over } 11 \text { years. }\end{array}$ \\
\hline OPEC Fund & 5.8 & 0.3 & Yes & $\begin{array}{l}\text { The OPEC Fund will partially provide assistance after } \\
\text { Completion Point by means of a new concessional US } \$ 6.0 \\
\text { million loan whose resources will be used to meet the debt } \\
\text { service navments due to the OPFC. Fund }\end{array}$ \\
\hline $\mathrm{NDF}$ & 5.4 & 0.2 & Yes & $\begin{array}{l}\text { NDF provides assistance after Completion Point through a } \\
\text { reduction of debt service payments on eligible debt by up to } 100 \\
\text { percent until the target of US } \$ 5.4 \text { million in NPV terms is } \\
\text { reached. Preliminarv estimates show that a NDF's relief could be }\end{array}$ \\
\hline BADEA & 7.1 & 0.3 & Yes & $\begin{array}{l}\text { Assistance will most likely be provided through a rescheduling } \\
\text { of principal payments and a reduction of interest rates. Precise } \\
\text { modalities are still to be finalized. }\end{array}$ \\
\hline Total multilateral & 1101.8 & 50.4 & n.a. & \\
\hline
\end{tabular}


Table 14. Ghana: Status of Creditor Participation Under Enhanced HIPC Initiative (concluded)

\begin{tabular}{|c|c|c|c|c|}
\hline & $\begin{array}{l}\text { Debt relief } \\
\text { in NPV terms } \\
\text { (US\$ millions) 1/ } \\
\end{array}$ & $\begin{array}{l}\text { Percentage of } \\
\text { total assistance }\end{array}$ & $\begin{array}{l}\text { Satisfactory } \\
\text { reply }\end{array}$ & $\begin{array}{l}\text { Modalities to } \\
\text { deliver debt relief }\end{array}$ \\
\hline Paris Club creditors & 826.9 & 37.8 & Yes & $\begin{array}{l}\text { Interim assistance has been provided through a flow rescheduling under } \\
\text { Cologne terms. Germany, Netherlands, Italy, USA and the UK have provided } \\
100 \text { percent flow cancellation, Japan and Spain provided } 100 \text { percent } \\
\text { rescheduling, and Canada } 95 \text { percent cancellation. }\end{array}$ \\
\hline Non-Paris Club creditors & 32.8 & 1.5 & & \\
\hline China & 8.7 & 0.4 & Yes & Some loans have been cancelled. \\
\hline India & 0.0 & 0.0 & No & Negotiations in progress. The amount is minimal. \\
\hline Korea & 4.4 & 0.2 & No & Negotiations are in progress. \\
\hline Kuwait Development Fund & 10.9 & 0.5 & Yes & Provided debt relief on Naples terms . \\
\hline Saudi Development Fund & 8.7 & 0.4 & Yes & $\begin{array}{l}\text { Provided interim flow relief on Naples terms. Will consider additional relief at } \\
\text { completion point. }\end{array}$ \\
\hline Commercial creditors & 223.0 & 10.2 & No & Being contacted by Ghana. \\
\hline Total bilateral and commercial & 1084.3 & 49.6 & & \\
\hline Total & 2186.1 & 100.0 & & \\
\hline
\end{tabular}

Sources : Ghanaian authorities; and Bank and Fund staff estimates.

$1 /$ The amount of assistance is estimated using the exchange rates at the decision point. 
Table 15. Paris Club Creditors' Delivery of Debt Relief Under Bilateral Initiatives Beyond the HIPC Initiative

\begin{tabular}{|c|c|c|c|c|c|c|c|}
\hline & \multirow[t]{2}{*}{ Countries covered } & \multicolumn{2}{|c|}{ ODA (in percent) } & \multicolumn{2}{|c|}{ Non-ODA (in percent) } & \multicolumn{2}{|c|}{ Provision of relief } \\
\hline & & $\begin{array}{r}\text { Pre-COD } \\
\text { (2) } \\
\end{array}$ & $\begin{array}{r}\text { Post-COD } \\
\text { (3) } \\
\end{array}$ & $\begin{array}{r}\text { Pre-COD } \\
(4) \\
\end{array}$ & $\begin{array}{r}\text { Post-COD } \\
\text { (5) } \\
\end{array}$ & $\begin{array}{r}\text { Decision point } \\
\text { (In percent) } \\
(6) \\
\end{array}$ & $\begin{array}{r}\text { Completion } \\
\text { point } \\
(7) \\
\end{array}$ \\
\hline Australia & HIPCs & 100 & 100 & 100 & $1001 /$ & $1 /$ & $1 /$ \\
\hline Austria & HIPCs (c-b-c) & c-b-c (100) & c-b-c (100) & c-b-c (100) & - & $c-b-c$ & $c-b-c$ \\
\hline Belgium & HIPCs & 100 & 100 & $c-b-c(100)$ & - & flow & Stock \\
\hline Canada & HIPCs $2 /$ & $-3 /$ & $-3 /$ & 100 & 100 & 100 flow & Stock \\
\hline Denmark & HIPCs & 100 & c-b-c (up to 100) & - & - & - & Stock \\
\hline France & HIPCs & 100 & 100 & 100 & - & 100 flow $4 /$ & Stock \\
\hline Finland & HIPCs & 95 & 98 & - & - & - & - \\
\hline Germany & HIPCs & 100 & 100 & 100 & - & 100 flow & Stock \\
\hline Ireland & - & - & - & - & - & - & - \\
\hline Italy & HIPCs & 100 & $1005 /$ & 100 & $1005 /$ & 100 flow & Stock \\
\hline Japan & HIPCs & 100 & 100 & 100 & - & - & Stock \\
\hline Netherlands & HIPCs & 100 & 100 & 100 & - & $90-100$ flow $6 /$ & Stock 6/ \\
\hline Norway & HIPCs & $-3 /$ & $-3 /$ & 100 & $1007 /$ & 100 flow & Stock \\
\hline Russia & $c-b-c$ & - & - & - & - & - & Stock \\
\hline Spain & HIPCs & 100 & $c-b-c$ & $c-b-c$ & $c-b-c$ & - & Stock \\
\hline Sweden & c-by-c & $-3 /$ & $-3 /$ & c-b-c (100) & - & - & Stock \\
\hline Switzerland & HIPCs & $1003 /$ & $-3 /$ & $1008 /$ & $c-b-c$ & $1008 /$ & Stock \\
\hline United Kingdom & HIPCs & 100 & 100 & 100 & $1009 /$ & 100 flow $9 /$ & Stock \\
\hline United States & HIPCs & 100 & 100 & 100 & 10010 & 100 flow & Stock \\
\hline
\end{tabular}

Source: Paris Club Secretariat

Note: Columns (1) to (7) describe the additional debt relief provided following a specific methodology under bilateral initiatives and need to be read as a each creditor. In column (1), "HIPCs" stands for eligible countries effectively qualifying for the HIPC process. A "100 percent" mention in the table mea debt relief provided under the enhanced HIPC Initiative framework will be topped up to 100 percent through a bilateral initiative. (Case-by-case, c-b-c)

1/ Australia: post-cutoff date non-ODA relief to apply to debts incurred before a date to be finalized; timing details for both flow and stock relief are to be 2/ Canada: including Bangladesh. Canada has granted a moratorium of debt service as of January 2001 on all debt disbursed before end-March 1999 for 1 of 17 HIPCs with debt service due to Canada. The debt will be written off at the completion point. The countries to be covered are: Benin, Bolivia, Came Ethiopia, Guyana, Honduras, Madagascar, Mali, Senegal, Tanzania, and Zambia.

3/ 100 percent of ODA claims have already been cancelled on HIPCs, with the exception of Myanmar's debt to Canada.

4/ France: cancellation of 100 percent of debt service on pre-cutoff date commercial claims as they fall due starting at the decision point. Once countries have reached their completion debt relief on ODA claims will go to a special account and will be used for specific development projects.

5/ Italy: cancellation of 100 percent of all debts (pre- and post-COD, ODA and non-ODA) incurred before June 20, 1999 (the Cologne Summit). At decisi point cancellation of the related amounts falling due in the interim period. At completion point cancellation of the stock of remaining debt

6/ The Netherlands: ODA: 100 percent ODA: pre- and post-cutoff date debt will be cancelled at decision point; for non-ODA: in some particular cases (1 Burkina Faso, Mali, Ethiopia, Nicaragua, and Tanzania), the Netherlands will write off 100 percent of the consolidated amounts on the flow at decision pc other HIPCs will receive interim relief up to 90 percent reduction of the consolidated amounts. At completion point, all HIPC countries will receive $100 \mathrm{~F}$ cancellation of the remaining stock of the pre-cutoff date debt.

7/ On debt assumed before December 31, 1997.

8/ Switzerland: In principle 100 percent cancellation of Pre-cutoff date non-ODA debt. However, Switzerland claims the right at the decision point to for 90 percent in case of major political and/or political weaknesses.

9/ United Kingdom: "beyond 100 percent" full write-off of all debts of HIPCs as of their decision points, and reimbursement at the decision point of any paid before the decision point.

10/ United States: 100 percent post-cutoff date non-ODA treated on debt assumed prior to 06/20/99 (the Cologne Summit). 
Table 16. HIPC Initiative: Status of Country Cases Considered Under the Initiative, end-May 2004

\begin{tabular}{|c|c|c|c|c|c|c|c|c|c|c|c|}
\hline \multirow[b]{2}{*}{ Country } & \multirow{2}{*}{$\begin{array}{r}\text { Decision } \\
\text { Point }\end{array}$} & \multirow{2}{*}{$\begin{array}{r}\text { Completion } \\
\text { Point }\end{array}$} & \multicolumn{2}{|c|}{$\begin{array}{c}\text { Target } \\
\text { NPV of Debt-to- } \\
\end{array}$} & \multicolumn{4}{|c|}{$\begin{array}{c}\text { Assistance Levels 1/ } \\
\text { (In millions of U.S. dollars, present value) }\end{array}$} & \multirow{2}{*}{\multicolumn{2}{|c|}{$\begin{array}{rr}\begin{array}{r}\text { Percentage } \\
\text { Reduction }\end{array} \\
\text { World in NPV of } \\
\text { Bank } \quad \text { Debt 2/ }\end{array}$}} & \multirow{2}{*}{$\begin{array}{r}\text { Estimated Total } \\
\text { Nominal Debt } \\
\text { Service Relief } \\
\text { (In millions of } \\
\text { U.S. dollars) }\end{array}$} \\
\hline & & & $\frac{\text { Exports }}{\text { (in pe }}$ & $\begin{array}{r}\text { Gov. } \\
\text { revenue } \\
\text { rcent) }\end{array}$ & Total & Bilateral & $\begin{array}{l}\text { Multi- } \\
\text { lateral }\end{array}$ & IMF & & & \\
\hline \multicolumn{12}{|c|}{ Completion point reached under enhanced framework } \\
\hline Benin & Jul. 00 & Mar. 03 & 150 & & 265 & 77 & 189 & 24 & 84 & 31 & 460 \\
\hline Bolivia & & & & & 1,302 & 425 & 876 & 84 & 194 & & 2,060 \\
\hline original framework & Sep. 97 & Sep. 98 & 225 & & 448 & 157 & 291 & 29 & 54 & 14 & 760 \\
\hline enhanced framework & Feb. 00 & Jun. 01 & 150 & & 854 & 268 & 585 & 55 & 140 & 30 & 1,300 \\
\hline Burkina Faso & & & & & 553 & 83 & 469 & 57 & 231 & & 930 \\
\hline original framework & Sep. 97 & Jul. 00 & 205 & & 229 & 32 & 196 & 22 & 91 & 27 & 400 \\
\hline enhanced framework & Jul. 00 & Apr. 02 & 150 & & 195 & 35 & 161 & 22 & 79 & 30 & 300 \\
\hline topping-up & $\ldots$ & Apr. 02 & 150 & & 129 & 16 & 112 & 14 & 61 & 24 & 230 \\
\hline \multicolumn{12}{|l|}{ Ethiopia } \\
\hline original framework & Nov. 01 & Apr. 04 & 150 & & 1,275 & 482 & 763 & 34 & 463 & 47 & 1,941 \\
\hline topping-up & & Apr. 04 & 150 & & 707 & 155 & 552 & 26 & 369 & 31 & 1,334 \\
\hline Guyana & & & & & 591 & 223 & 367 & 75 & 68 & & 877 \\
\hline original framework & Dec. 97 & May 99 & 107 & 280 & 256 & 91 & 165 & 35 & 27 & 24 & 440 \\
\hline enhanced framework & Nov. 00 & Dec-03 & 150 & 250 & 335 & 132 & 202 & 40 & 41 & 40 & 437 \\
\hline Mali & & & & & 539 & 169 & 370 & 59 & 185 & & 895 \\
\hline original framework & Sep. 98 & Sep. 00 & 200 & & 121 & 37 & 84 & 14 & 43 & 9 & 220 \\
\hline enhanced framework & Sep. 00 & Mar. 03 & 150 & & 417 & 132 & 285 & 45 & 143 & 29 & 675 \\
\hline Mauritania & Feb. 00 & Jun. 02 & 137 & 250 & 622 & 261 & 361 & 47 & 100 & 50 & 1,100 \\
\hline Mozambique & & & & & 2,023 & 1,270 & 753 & 143 & 443 & & 4,300 \\
\hline original framework & Apr. 98 & Jun. 99 & 200 & & 1,717 & 1,076 & 641 & 125 & 381 & 63 & 3,700 \\
\hline enhanced framework & Apr. 00 & Sep. 01 & 150 & & 306 & 194 & 112 & 18 & 62 & 27 & 600 \\
\hline Nicaragua & Dec. 00 & Jan-04 & 150 & & 3,308 & 2,175 & 1,134 & 82 & 191 & 73 & 4500 \\
\hline \multicolumn{12}{|l|}{ Niger } \\
\hline original framework & Dec. 00 & Apr. 04 & 150 & & 521 & 211 & 309 & 28 & 170 & 54 & 944 \\
\hline topping-up & & Apr. 04 & 150 & & 143 & 23 & 119 & 14 & 70 & 25 & 246 \\
\hline Senegal & Jun. 00 & Apr. 04 & 133 & 250 & 488 & 212 & 276 & 45 & 124 & 19 & 850 \\
\hline Tanzania & Apr. 00 & Nov. 01 & 150 & & 2,026 & 1,006 & 1,020 & 120 & 695 & 54 & 3,000 \\
\hline Uganda & & & & & 1,003 & 183 & 820 & 160 & 517 & & 1,950 \\
\hline original framework & Apr. 97 & Apr. 98 & 202 & & 347 & 73 & 274 & 69 & 160 & 20 & 650 \\
\hline enhanced framework & Feb. 00 & May 00 & 150 & & 656 & 110 & 546 & 91 & 357 & 37 & 1,300 \\
\hline \multicolumn{12}{|c|}{ Decision point reached under enhanced framework } \\
\hline Cameroon & Oct. 00 & Floating & 150 & & 1,260 & 874 & 324 & 37 & 179 & 27 & 2,000 \\
\hline Chad & May. 01 & Floating & 150 & & 170 & 35 & 134 & 18 & 68 & 30 & 260 \\
\hline Congo, Democratic Rep. of & Jul. 03 & Floating & 150 & & 6,311 & 3,837 & 2,474 & 472 & 831 & 80 & 10,389 \\
\hline Gambia, The & Dec. 00 & Floating & 150 & & 67 & 17 & 49 & 2 & 22 & 27 & 90 \\
\hline Ghana & Feb. 02 & Floating & 69 & 250 & 2,186 & 1,084 & 1,102 & 112 & 781 & 56 & 3,700 \\
\hline Guinea & Dec. 00 & Floating & 150 & & 545 & 215 & 328 & 31 & 152 & 32 & 800 \\
\hline Guinea-Bissau & Dec. 00 & Floating & 150 & & 416 & 212 & 204 & 12 & 93 & 85 & 790 \\
\hline Honduras & Jul. 00 & Floating & 110 & 250 & 556 & 215 & 340 & 30 & 98 & 18 & 900 \\
\hline Madagascar & Dec. 00 & Floating & 150 & & 814 & 457 & 357 & 22 & 252 & 40 & 1,500 \\
\hline Malawi & Dec. 00 & Floating & 150 & & 643 & 163 & 480 & 30 & 331 & 44 & 1,000 \\
\hline Rwanda & Dec. 00 & Floating & 150 & & 452 & 56 & 397 & 44 & 228 & 71 & 800 \\
\hline São Tomé and Príncipe & Dec. 00 & Floating & 150 & & 97 & 29 & 68 & - & 24 & 83 & 200 \\
\hline Sierra Leone & Mar. 02 & Floating & 150 & & 600 & 205 & 354 & 123 & 122 & 80 & 950 \\
\hline Zambia & Dec. 00 & Floating & 150 & & 2,499 & 1,168 & 1,331 & 602 & 493 & 63 & 3,850 \\
\hline \multicolumn{12}{|l|}{ Preliminary HIPC document issued } \\
\hline Côte d'Ivoire & Mar. 98 3» & $\cdots$ & 141 & 280 & 345 & 163 & 182 & 23 & 91 & 6 & 800 \\
\hline Total assistance provided/com & & & & & 32,325 & 15,686 & 16,503 & $2,5575 /$ & 7,669 & & 53,416 \\
\hline \multicolumn{12}{|c|}{ Preliminary HIPC document issued } \\
\hline Côte d'Ivoire 6/ & $\ldots$ & $\ldots$ & 91 & 250 & 2,569 & 1,027 & 918 & 166 & 438 & 37 & 3,900 \\
\hline
\end{tabular}

Sources: IMF and World Bank Board decisions, completion point documents, decision point documents, preliminary HIPC documents, and staff calculations.

1/ Assistance levels are at countries' respective decision or completion points, as applicable.

2/ In percent of the net present value of debt at the decision or completion point (as applicable), after the full use of traditional debt-relief mechanisms.

3/ Côte d'Ivoire reached its decision point under the original framework in March 1998. The total amount of assistance committed thereunder was US\$345 million in NPV

4/ Nonreschedulable debt to non-Paris Club official bilateral creditors and the London Club, which was already subject to a highly concessional restructuring, is

excluded from the NPVof debt at the completion point in the calculation of this ratio.

5/ Equivalent to SDR 1,721 million at an SDR/USD exchange rate of 0.6730, as of December 1, 2003.

6/ It is suggested that enhanced HIPC relief for Côte d'Ivoire overtake the commitments made under the original HIPC framework. 